\title{
Impacts of the U.S. subsidy to soybeans on World prices, production and exports ${ }^{1}$
}

\author{
Antônio Salazar P. Brandão² \\ Elcyon Caiado Rocha Lima ${ }^{3}$
}

\begin{abstract}
This paper specifies and estimates an econometric model of the soybean market (grain, oil and meal) to assess the effects of U.S. domestic support to soybeans on world soybean prices, production and exports.

The model divides the world into five regions (modules): Argentina, Brazil, the European Union, the United States (US) and the Rest of the
\end{abstract}

1 This paper has been prepared at the request of the Confederação Nacional da Agricultura e Pecuária do Brasil (CNA) as a partial fulfillment of agreement $\mathrm{n}^{\circ}$ 21.010.830/2001-12 signed by the CNA and the Ministério da Agricultura, Pecuária e Abastecimento to assess the effects of U.S. domestic support to soybeans on the Brazilian soybean sector. The authors want to express their gratitude to several people and institutions: the participants of the various meetings and seminars headed by Pedro de Camargo Netto who was then Secretary of Production and Marketing, Ministério da Agricultura e do Abastecimento; to ABIOVE staff who shared information and knowledge of U.S. policy with us; to Guilherme Leite da Silva Dias, Sávio Pereira, Getúlio Pernambuco and Fábio Trigueirinho who have had extensive discussions with us and contributed significantly to the conception of the model and to our understanding of U.S. agricultural policy; to the OECD Agricultural Directorate who shared their knowledge of agricultural policies in the OECD countries and their modeling experience with us. We have also benefited enormously from data and other information contained in AgLink (which was accessible to us through the agreement of Ministério da Agricultura and the OECD). None of those mentioned above are responsible for the errors and omissions that may still remain.

${ }^{2}$ Professor of the State University of Rio de Janeiro (UERJ). abrandao@firjan.org.br

${ }^{3}$ Researcher at IPEA and Professor of the State University of Rio de Janeiro (UERJ). elcyon@ipea.gov.br 
World (ROW). There are interactions between the modules through the international prices and the net exports of each soybean product. The international prices of grain, oil and meal are endogenous and are determined equating net exports of the first four modules (Argentina, Brazil, European Union and the U.S.) to net imports of the ROW. The analysis is conducted eliminating the U.S. domestic support to soybeans and simulating the impacts on the variables of interest. The simulations show a significant impact of the US subsidy to soybeans on world prices and net exports of the four selected regions.

Key words: soubeans subsidy, soybean market, international trade.

\section{JEL Classification: F17, Q17}

Resumo: Este trabalho estima um modelo econométrico do mercado de soja e derivados com o objetivo de avaliar os efeitos das políticas de apoio interno dos Estados Unidos sobre os preços internacionais, sobre a produção e sobre as exportações.

O modelo divide o mundo em cinco regiões: Argentina, Brasil, Estados Unidos, União Européia e Demais países. A interação entre as regiões ocorre através dos preços internacionais e pelas exportações líquidas em cada um dos mercados. Os preços internacionais dos três produtos são determinados igualando-se a soma das exportações líquidas das cinco regiões.

A análise é feita eliminando o apoio doméstico nos Estados Unidos e simulando o impacto nas variáveis de interesse. As simulações mostram impactos significativos do subsídio americano sobre os preços internacionais e sobre as exportações líquidas de Argentina, Brasil, Estados Unidos e União Européia.

Palavras-chave: subsídio à soja, mercado da soja, comércio internacional.

Classificação JEL: F17, Q17 


\section{Introduction ${ }^{4}$}

The Farm Bill of 1996, the Federal Agriculture Improvement and Reform (Fair) Act, introduced significant changes in U.S. agricultural policy. This partial reform of agricultural policy was an attempt to reduce budget expenditures and to meet agreements signed in the Uruguay Round. Traditional types of assistance, mostly based on current production and market conditions, were discontinued in favor of decoupled payments (called production flexibility contracts, PFC) not associated with current production or area. All acreage restrictions were eliminated.

With the fall in prices after 1997, U.S. government expenditures with Amber Box support (not excluding de minimis exemptions) went from US $\$ 7$ billions in 1997, to US\$ 14 billion in 1998, to US $\$ 23$ billion in 1999 and fell slightly to US\$ 21 billion in 2000 (Hart and Babcock, Table 2, p. 10). Support for soybeans under this category increased from almost zero in 1997 to US\$ 1.3 billion in 1998, to US\$ 2.8 billion in 1999 and 2000.

Payments based on historical programs (the same as the PFCs), which have replaced the old Loan Deficiency Payments, have been another major component of U.S. support to agriculture. Expenditures under this heading went from US\$ 5.2 billion in 1996, to US\$ 6.3 billion in 1997, to US\$ 8.4 billion in 1998, to US\$ 10.9 billion in 1999 and have fallen slightly to US\$ 10.5 billion in 2000 (OECD).

Soybeans have benefited from the U.S. commodity loan programs since 1941, but were not subjected to the acreage restrictions imposed on feed grains, rice, wheat and upland cotton (Westcott and Price, p.15). In most of the period after 1970 market prices have been above the loan rate and the main benefit of the program was to provide liquidity to farmers until production was sold. This was not the case before 1970 and in the middle of the decade of the 1980s (see Westcott and Price pp. 16 and 17).

The marketing loan program in the U.S. started in 1986 for rice and upland crop and was extended to soybeans and other oilseeds in 1991

\footnotetext{
${ }^{4}$ This paper was prepared in 2002 to support the the WTO panel against the U.S. domestic support policies for soybeans that was Brazil was then considering. Due to changes in the world soybeans market, with significant price increases, the WTO panel was not requested. We submitted for publication the original version of the paper, without updating the data and model estimation.
} 
(Westcott and Price, p.3) and to wheat and feed grains in 1993. The Fair Act continued the market loan program for these crops.

The PFC payments, introduced by the Fair Act, were an attempt to move towards income support rather than price support. Producers of commodities previously eligible for deficiency payments were entitled to payments based the area planted with such crops during the 5-year period previous to 1996. Soybeans were not eligible for PFC payments.

The PFC payments have been considered by U.S. policy makers and by the WTO official decoupled with no or small effect on current production and on trade. However, time has shown that what seemed true in principle was not so in practice. With the elimination of acreage controls the PFC payments provided extra operating capital that allowed farmers to expand area. This took place for products that had higher returns per hectare. The increase in the loan rate for soybeans US $\$ 5.26$ per bushel in the 1997/98 marketing year triggered a substantial expansion of soybean acreage at the expenses of other crops, mainly wheat. But the production and trade distortions became even more evident with the Farm Security and Rural Investment Act (FSRIA) of 2002 that allowed changes in base acreage and yield and, as such, introduced an expectation element in the farmer's decision process. In other words, farmers that grow soybeans (and other products included in the policy) now will be eligible to receive the subsidies of the 2008 Farm Bill. That is, tomorrow's subsidies induce more production, more exports and lower world prices today. This is clearly a non-decoupled form of domestic support.

After 1999 the U.S. government introduced direct payments to soybean producers (the Oilseed Program). These payments were introduced after marketing loss assistance was granted to other crops and they are based on past areas and yields. Nevertheless, these payments have effects that are similar to the PFCs and are likely to raise current production in the U.S., raise U.S. exports and further reduce world prices of soybeans.

The Farm Security and Rural Investment Act (FSRIA) of 2002 did not change principles embedded in the earlier policy and introduced counter cyclical payments that provide a guarantee against low prices. Again these payments are based on past acreage and yield, but through expectations they will increase U.S. production and exports and will depress world prices in the present. 
In this paper we assess the effects of the U.S. domestic support to soybeans and its consequences to world prices and to Brazilian production and exports. To achieve this we first built an econometric model of the world soybean market. The counter factual analysis consisted of the elimination of the U.S. domestic support to soybeans and to track the impacts on the variables of interest.

The paper is organized as follows: section 2 presents stylized facts about the production of soybeans in the U.S. and Brazil; section 3 describes the U.S. Marketing Assistance Loan Program and other policies that have distorting effects on production, trade and world prices; section 4 lays down the principal characteristics of the econometric model used to estimate the impact of domestic support in the U.S. on world prices and Brazilian production and exports; section 5 contains the principal results and section 6 concludes the paper.

\section{Stylized facts}

U.S. acreage for products where area was tied to deficiency payments before the Fair Act decreased substantially after 1996. Between 1996 and 2000 area reductions were as follows: corn 1.9 million hectares; wheat 5.0 million hectares; sorghum 1.6 million hectares; and barley 506 thousand hectares. During the same period the increase in soybeans area was 4.2 million hectares ${ }^{5}$, which shows that the change in legislation had a major impact on the area planted with this crop.

Production of soybeans increased mostly because of area, since yields did not change during this period ${ }^{6}$. This is seen in Table 1 that displays area, production and yield for the period 1979/2001. Production increased 17 percent between 1996 and 2001, area increased 19 percent and yield, declined 1 percent over the same period ${ }^{7}$. Figure 1, which is based on indices of three-year averages, shows the same data.

The corresponding data for Brazil are shown in Table 2 and Figure 2,

\footnotetext{
${ }^{5}$ Area increases were also observed in cotton (358 thousand hectares); sunflower (104 thousand hectares) and rice (98 thousand hectares).

${ }^{6}$ Yield is a partial index of productivity. A more appropriate indicator is the total factor productivity index, whose calculation goes beyond the scope of this analysis.

${ }^{7}$ These are based on the three-year averages.
} 
where it can be seen the strong expansion of both area and yield during the same period. But the key difference is that domestic support has not changed at all during this period in Brazil, while this was not the case in the U.S.. A significant policy change that took place recently in Brazil was the elimination of the value added tax (ICMS) on exports of agricultural and semi processed goods in 1996. In other words, market forces have driven the strong performance displayed by the sector in Brazil.

Figure 3 shows the volume of U.S. soybeans exports since 1990. After the loan rate was raised to US\$ 5.26 per bushel in the 1997/1998-crop year exports have jumped, increasing 11 percent between 1997 and 1999 and 21 percent between 1998 and 1999. U.S. exports have been expanding since 1990, as figure 3 shows; however, from 1998 to 2001 they have shown additional vigor. This is particularly disturbing in light of the fact that the U.S. dollar has become stronger over this period, that world prices have been declining and that yields have not increased (Figure 4 shows export volumes and yield indices).

These elements show clearly that marketing assistance loan program have played a major role to explain the evolution of production and exports. In other words, while in Brazil the market has been the driving force behind the expansion of the soybean sector, in the U.S. the recent expansion is induced by government expenditures to support the sector.

\section{The U.S. Marketing Loan Assistance, Fixed Payments and Counter Cyclical Payments}

The US Marketing Loan Assistance Program operates through two instruments:

- Loan Rates; and

- Marketing Loans.

Loan Rates. The Marketing Loans for soybeans started in 1991. Before their introduction only Loan Rates were available. These allow soybean farmers to borrow from the government with production pledged as loan collateral. The loan value is determined by a crop specific loan rate per unit of production. Farmers can borrow anytime after harvest through May 31. Most of the operations occur shortly after harvest when prices are seasonally low. 
Loan repayment can be made in either of the forms below:

- payment of the principal plus interest; or

- forfeiting ownership of the loan collateral and keeping the proceeds of the loan.

Marketing Loans. Marketing loans changed significantly the operation of the program. Farmers are allowed to repay the loans at prices below the original loan rate plus interest. This is likely to occur when market prices are below the loan rates.

With marketing loans the government accumulation of stocks is reduced, since farmers retain ownership of production and sell directly on the market. In consequence the policy has removed the price support mechanism embedded in the Loan Program before.

The benefits of the program to farmers are granted through two different channels:

- Loan Program. In this case production is pledged as collateral for the loan in the same form described before. But farmers can repay the loan, at anytime during the loan period, at market prices. For soybeans the repayment prices are posted county prices that are calculated daily. The difference between the Loan Rate and the county prices represents a benefit of the program for producers. Notice also that no interest accrues on the loan when the loan repayment rate is below the loan rate plus interest.

- Loan Deficiency Payment (LDP). In this case farmers do not take any loans and the benefit of the program is the difference between the loan rate and the county prices. If an LDP is paid on portion of a crop it is no longer eligible for a loan.

The benefits of the Marketing Loan feature of the program have been, on average, higher than described above. This is due to the fact that farmers retain ownership of production and to the fact that the Loan Rate no longer provides price support. Thus the decision to take the benefit of the Marketing Loan is independent of the decision to sell production.

Typically a farmer will take the benefit of the program at the time market prices are seasonally at the lowest point and sell the crop later when prices are high again. Westcott and Price conclude the following from this:

Raising the realized per-unit revenue above the loan rate also increases the economic incentive to plant crops. This further encou- 
rages producers to plant more land to supported crops than they otherwise would and, as discussed earlier, may also influence the mix of crops planted. (p. 7)

Based on 1999 information, Westcott and Price (p.8) show the following for soybeans:

Season average price:

Marketing loan benefit: \$4.65/bushel;

$\$$ 0.85/bushel; (95 percent of the crop received a marketing loan benefit; about 88 percent received and LDP with an average payment rate of $\$$ $0.91 /$ bushel and 7 percent received a loan gain of $\$ 0.76 /$ bushel)

Average per-unit revenue: $\quad \$ 5.50 /$ bushel;

Commodity Loan Rate (1999): \$ 5.26/bushel; and

Revenue above Loan Rate: \$ $\quad$ 0.24/bushel.

Thus, the marketing loan benefit amounts to 18.28 percent of the season average price and the revenue above the loan rate amounts to 5.16 percent.

Westcott and Price (2001) have estimated the impact of this subsidy on world prices and other variables. Selected parts of their analysis and conclusions are quoted below:

"Soybean plantings are higher with marketing loans through 2004 except in 2000 ...Marketing loan benefits increase soybean net returns relative to returns to other crops in most years of the simulations, providing an economic incentive to plant more soybeans. In 2000, however, relatively large marketing loan benefits for corn pull away land from soybeans.” (p. 17)

"Exports of soybeans are increased through 2004, except in 2000 when corn program benefits lead to lower soybean plantings. Exports of soybean meal and soybean oil rise as well when soybean acreage increases as higher domestic crush of soybeans leads to higher production and lower prices in soybean product market." (p. 17)

“...when marketing loan benefits shift land into soybeans (2001 
through 2004) prices for soybeans are reduced, with the largest impact of 49 cents occurring in 2001 when acreage gains for the crop are highest.” (p. 19)

In the simulation made by these author's, the impacts on prices from 1998 to 2000 are minor; the highest is in 2001 when the marketing assistance loan reduces prices by 49 cents per bushel, corresponding roughly to a reduction of 10 percent relative to the baseline with the marketing loan assistance ${ }^{8}$.

Westcott and Price (2001) analysis takes into account the following crops: wheat, corn, sorghum, barley, oats, soybean, rice and cotton. The effect of the marketing loan assistance on area planted is larger from 1999 to 2001 with acreage increases of 810 to 1.6 million hectares ${ }^{9}$ relative to the no marketing loan assistance scenario. As inspection of figures 20 to 24 (p. 16) of the paper indicates that the effects on upland cotton and on soybeans are the largest relative to those on wheat, corn and rice. A similar conclusion regarding to exports is suggested by figures 25 to 30 , with the difference that impacts on rice exports are large too. And for prices, other than soybean, the conclusion of the authors is that:

"In 1999 through 2001, wheat prices are lowered 4 to 7 cents per bushel in the marketing loan simulation, while corn prices are reduced 3 to 9 cents per bushel in 1999 and 2000.... Rice prices are reduced throughout the simulation period, with declines of 10 to 20 cents per hundredweight in 2000 through 2005. Simulated price reductions for upland cotton range from 1 to 5 cents per pound through 2002, the years of the largest cotton acreage increase due to marketing loan benefits." (p. 19).

OECD (2000, p. 59) has performed a similar exercise. They have assumed that:

- there were no loan program payments for other crops and that other countries' policies remain unchanged; and

\footnotetext{
${ }^{8}$ The paper does not contain tables. The percentage mentioned in the text is based on inspection of Figure 34, page 20.

${ }^{9}$ This is equivalent to 2 to 4 million acres.
} 
- the marketing loans to be US\$ 49/ton in $2000^{10}$; US\$ 43/ton in 2001; US\$ 31/ton in 2002; US\$ 21/t in 2003; US\$2/t in 2004 and zero in 2005. Based on these assumptions, they have concluded that:

"The withdrawal of such payments leads to lower soyabeans output (initially -5 percent) and increase the output of maize (initially +2 percent) and wheat (initially +1 percent). These production changes have temporary impacts on export levels and world prices. Initially world prices of soyabeans are 6 to 7 percent higher while world maize price are 3 percent lower. However, these effects are eroded by 2004 as markets adjust.” (OECD 2000, p. 59)

These studies indicate clearly that the Marketing Assistance Loan Program does have effects on world soybean prices and trade. However the impacts on Brazil's production and exports are not mentioned in the papers and cannot be inferred from their results. A dedicated model, where Brazil in explicitly included, is needed to make this assessment.

Direct payments for oilseeds were introduced in the crop year $1999 / 2000$ based on past acreage and yields. They not only have been maintained by the FSRIA but were raised from about US $\$ 0,15$ per bushel to US $\$ 0,44$ per bushel. These payments are now specific to soybeans and are based on the acreage and yields of the period 1998/2001. As before they are likely to be treated as decoupled by the $\mathrm{WTO}^{11}$.

The FSRIA reduced the loan rate for soybeans from US\$ 5.26 per bushel to US\$ 5.00 per bushel for the period 2002-2007.

The counter cyclical payments are a novelty of the FSRIA in comparison with the FAIR Act. These are based on a target price whose value is US\$ 5.80 per bushel until 2007. The counter cyclical payments are determined by the following formula:

\section{Target price - (higher of farm price or loan rate) - direct payment}

Counter cyclical payments are based on area and yield of soybeans during past periods, and are likely to be treated as decoupled by the $\mathrm{WTO}^{12}$.

\footnotetext{
${ }^{10}$ The actual value of the marketing loan assistance in 2000 was US $\$ 37 /$ ton (calculations based on Hart and Babcock, 2001, Table 2 and the U.S. production of 75,055 million tons).

${ }^{11}$ Please see the introduction where we have argued that these payments are trade distorting.

${ }^{12}$ Please see the introduction where we have argued that these payments are trade distorting.
} 
For the sake of completeness, we indicate below the methodology established by the FSRIA to determine acreage and yields for both direct and counter cyclical payments.

\section{For direct payments}

Soybean area is the average area during 1998/2001. (Farm Economics Facts \& Opinions, June 5, 2002, no page numbers) Soybean yields, for the purpose of direct payments, are calculated as follows: average of soybean yields from 1998 through 2001 times .7814. The .7814 equals the ratio of the national soybean yields between 1981

through 1985 to national yields from 1998 to 2001. This adjustment keeps soybean program yield on a comparable base with corn and wheat yields. If a farm yield form 1998 through 2001 is below 75\% of the county yield, the farm yield can be replaced by $75 \%$ of the county yield. (Farm Economics Facts \& Opinions, June 5, 2002, no page numbers)

\section{For counter cyclical payments}

The area is determined exactly as in the case of the direct payments. For the determination of yields however the farmer may choose from three methodologies, as indicated below. (Farm Economics Facts \& Opinions, June 5, 2002, no page numbers)

Program yield, which is determined by the same procedure used in the direct payments program.

The $\mathbf{7 0} \%$ difference method where yield is equal to the program yield plus $70 \%$ of the difference between the average yield for 1998 through 2001 and the program yield.

The $\mathbf{9 3 . 5 \%}$ method where yield is equal to $93.5 \%$ of the average yield during the period1998 to 2001.

With the increase in direct payments and the introduction of counter cyclical payments the FSRIA increased domestic support to soybean pro- 
ducers relative to the previous legislation. The raise in other payments more than compensated the reduction of the loan rates. For comparison purposes, assume that soybean market price, in the crop year 2002/2003, is US\$ 4.45 per bushel and that acreage and yield of a typical farmer remain constant. A hypothetical comparison of the support received before and after the FSRIA made below:

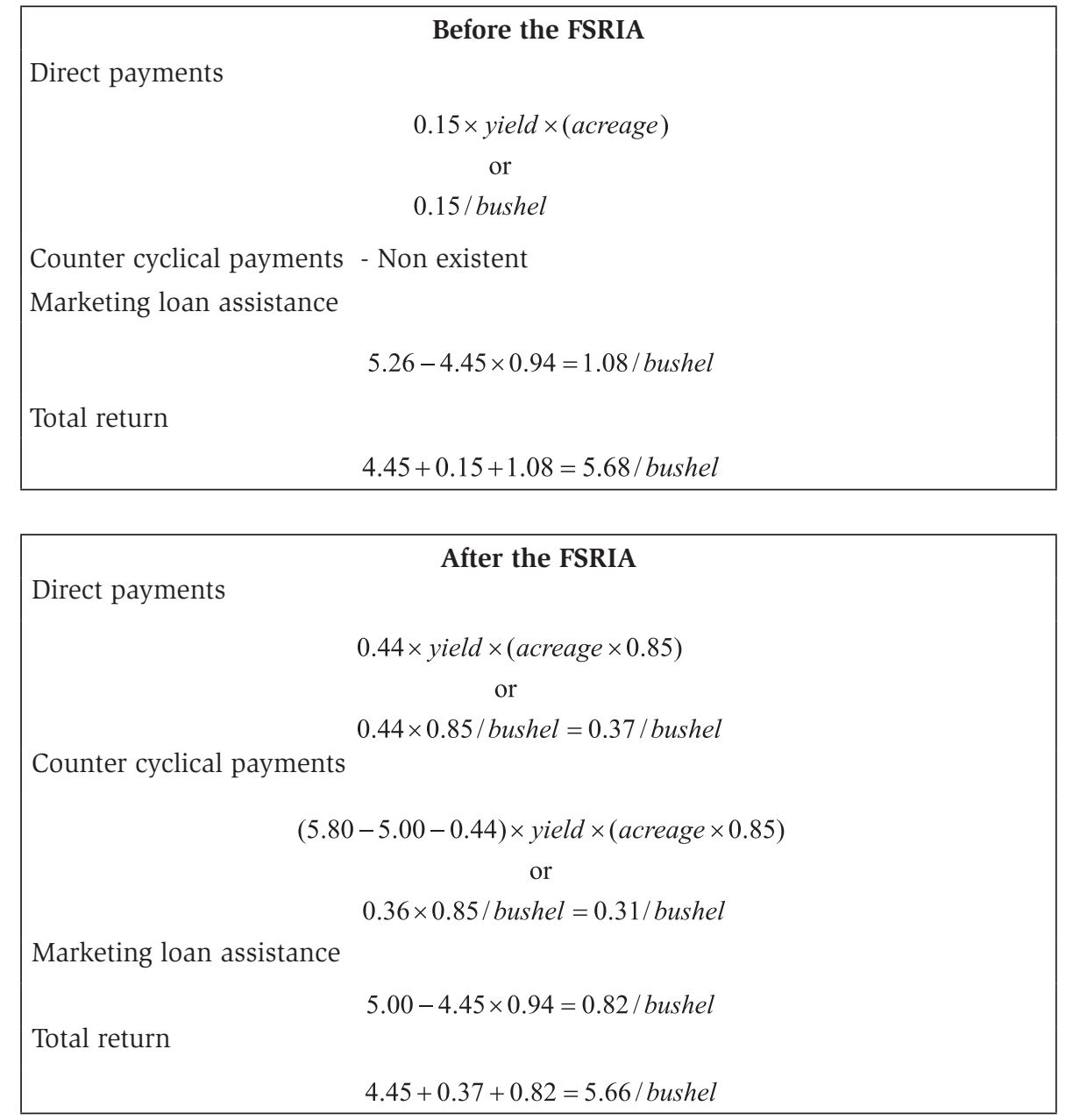

As seen in the two boxes above the FSRIA raises total return by $4.75 \%$. If the WTO accepts the view that direct and counter cyclical payments are decoupled, the part of the support that is considered non-trade distorting 
has actually decreased from US\$ 1.08 /bushel to US\$ $0.82 /$ bushel. This is a critical issue for the next round of trade negotiations and for the soybean panel against the U.S. in the WTO.

\section{Model structure and experiments}

This section lays down the main aspects of the world soybean model, describes the steps to simulate the policy change and the counter factual analysis.

The world is divided into five regions (modules): Argentina, Brazil, the European Union, the United States (US) and the Rest of the World (ROW). The diagrams in Annex III show the model structure for each module.

For each module, area and yield equations determine the supply of soybeans. The domestic demand for soybeans by the crushing industry and the domestic demand for "Other Uses" of soybeans are estimated" After determining the demand for crushing, "Other Uses" and soybeans supply, net exports are obtained from the identity:

net exports $=$ production - crushing demand - other uses

Productions of oil and meal are fixed proportions of the volume of soybeans crushed. These are, in turn, divided in two parts: net exports and "Other Uses". We estimate equations for net exports of soybean meal and for "Other Uses" of soybean oil.

Net imports of soybeans, soybean oil and soybean meal of the rest of the world are exogenous, which means that they are not affected by the elimination of the U.S. Marketing Assistance Loan and other policies.

Equating net exports of the first four modules (Argentina, Brazil, European Union and the U.S.) to net imports of the ROW determines the international price of grain, oil and meal. These prices are expressed in domestic currency units, in real terms, by multiplying the dollar values by the region real exchange rate.

Equations linking the international price in domestic currency, to the domestic prices in domestic currency - price transmission equations - for the three products are also estimated. This is done with due consideration

\footnotetext{
${ }^{13}$ The exception is the European Union where a net import equation was estimated and other uses were calculated as a residual.
} 
of domestic policies that may have affected this relation, such as the elimination of the export tax on soybeans in Brazil in 1996.

The equations of the model, with the respective coefficients and statistics, are presented in Annex I. All variables have the correct signs and are significant. There is no evidence of autocorrelation of the residuals and the fit of model within the sample is good.

Comparing the baseline scenario with one where no subsidy exists allows for the estimation of the effects of the changes in policies. The baseline consists of the model forecasts for the period where data is available and of the projections, based on the relevant parameters of the FSRIA.

The two scenarios considered in the counter factual analyses are described below:

- Scenario 1. WTO rules are not changed and the Marketing Loan Assistance is the only policy that influences U.S. exports and world prices. This scenario is consistent with the lower impact on world prices and on world trade.

- Scenario 2. In addition to Marketing Loan Assistance, direct payments and counter cyclical payments are removed. This gives an upper bound for the impacts on world prices and world trade.

It is clear that neither the direct payments nor the counter cyclical payments are entirely decoupled, as assumed in Scenario 2 . The impact of these two subsidies on production and exports depend on expectations regarding the next farm bill in 2007 and, as such, their effects may be smaller than those indicated in the simulations below. Nevertheless, the two scenarios give a reasonable range of variation for the variables relevant for this analysis.

\section{Results}

Table 3 shows values of the subsidy from 1998 to 2001. The values for the period 2002 to 2004 are estimated taking into account the FSRIA and prices generated by the baseline (scenario 1) of the econometric model. Total return is what farmers receive above market price due to the marketing loan, direct payments and counter cyclical payments. 
Table 3 - U.S. Marketing Loan Payments - US\$/bushel

\begin{tabular}{cccccccc}
\hline & $(1)$ & $(2)$ & $(3)$ & $(4)$ & $(5)$ & $(6)$ & $(7)$ \\
\hline \multicolumn{1}{l}{ Years } & $\begin{array}{c}\text { Loan } \\
\text { Rate }\end{array}$ & $\begin{array}{c}\text { Producer } \\
\text { Price }^{*}\end{array}$ & $\begin{array}{c}\text { Adjustment } \\
\text { factor }(\%)^{* *}\end{array}$ & $\begin{array}{c}\text { Marketing } \\
\text { loan payments } \\
(1)-(3) \times(2)\end{array}$ & $\begin{array}{c}\text { Direct pay- } \\
\text { ment }{ }^{* * *}\end{array}$ & $\begin{array}{c}\text { Counter } \\
\text { cyclical } \\
\text { payments }\end{array}$ & $\begin{array}{c}\text { Producer } \\
\text { return }\end{array}$ \\
\hline 1998 & 5.26 & 4.93 & 0.98 & 0.45 & 0.00 & 0.00 & 5.38 \\
1999 & 5.26 & 4.63 & 0.95 & 0.87 & 0.14 & 0.00 & 5.63 \\
2000 & 5.26 & 4.55 & 0.91 & 1.11 & 0.15 & 0.00 & 5.81 \\
2001 & 5.26 & 4.25 & 0.94 & 1.25 & 0.15 & 0.00 & 5.65 \\
2002 & 5.00 & 4.55 & 0.94 & 0.72 & 0.44 & 0.36 & 5.95 \\
2003 & 5.00 & 4.55 & 0.94 & 0.72 & 0.44 & 0.36 & 5.95 \\
2004 & 5.00 & 4.55 & 0.94 & 0.72 & 0.44 & 0.36 & 5.95 \\
\hline
\end{tabular}

Source: USDA and Farm Security and Rural Investment Act, 2002.

* After 2001 estimated prices.

** The adjustment factor considers that the contract is closed at the lowest value of the season's market price. After 2001 estimated based on the 2001 value.

*** Oilseed program until 2001. After 2001, Farms Security and Rural Investment Act.

In Scenario 1 the values of the marketing loan payments are reduced to zero. In the Scenario $\mathbf{2}$ the producer return is the same as producer price, that is, the marketing loan payments, the direct payments and the counter cyclical payments are all reduced to zero.

Scenario 1. Tables 4 to 13 contain results of simulations. Table 4 contains estimated price changes due to the removal of the marketing loan assistance. The average increase in world prices increase over the period 1998/2004 in 3.95 percent, with highest values, of the order of 7 percent, in 2000 and in 2001 when the marketing loan payments were at their peak. It is seen that producer prices in the U.S. are reduced on average 11.48 percent and Brazilian prices increase by about 3.81 percent, in line with the change in world prices.

It must be noted that the world price changes estimated by the model are in line with those obtained in other studies, such as those of Westcott and Price $(1999,2001)$ and the OECD Agricultural Outlook (2000). The fact that removing large subsidies to commodities does not cause large impacts on market prices is well known and documented in the literature, as noted by Valdés and Foster (2002). 
The changes in world oil and meal prices are seen in Table 5 . The average impact on oil prices is quite surprising, since it is even higher than the impact on grain prices. This is caused by the large reduction on crushing in the U.S. and by the small effect on domestic consumption. Meal prices, on the other hand, increase less than soybean world prices.

Table 6 shows the impacts on soybeans production in Argentina, Brazil and the U.S.. There is a reduction of approximately 30 million tons during the period 1998/2004 in the U.S. production of soybeans, which correspond to approximately 5.3 percent of the production estimated in the baseline. This is, in part, compensated by increases in Argentina and Brazil of the order of 4 percent in each country. The largest impacts on Brazil take place during the period 2001 and 2003, where production losses between 2 and 2.5 million tons per year.

Tables 7, 8 and 9 show the corresponding impacts on soybean oil production, soybean meal production and in soybean crushing. These impacts are in line with the changes observed in world prices and in soybeans production. Notice that the impact on Brazil is quite significant compared with that of Argentina and of the European Union.

In summary, the analysis of these tables indicate that the removal of the marketing loan assistance in the U.S. will have favorable impacts on soybean production as well as on the domestic crushing industry.

Tables 10 to 13 show net exports. The results indicate again that the impact of the removal of this subsidy on the world market is significant. Exports from the U.S. would be smaller (about 3 million tons in 2002) and those of Brazil and Argentina increased. In Brazil the highest impact is in 2001, about 2 million tons, and the impact, during the period 1998/2004, is of the order of 7 million tons. The impact on the value of exports, as seen in Table 11, is close to US $\$ 2$ billion dollars, with the largest values (US\$ 450 and US\$ 382 millions) concentrated in 2001 and 2002.

By the total value of net exports of the soybean complex are larger, since Brazilian exports of soybean oil and soybean meal will increase too. The total effect reaches the value of US\$ 751 million in 2001, dropping to US 699 millions in 2002. The total increment of exports of the soybean complex during the period is US\$ 3 billion.

These results illustrate another perverse aspect of the current concepts used in the WTO regarding export subsidies. The marketing loan 
assistance is defined as domestic support (Amber Box). However, its impacts on U.S. exports are large relative to the change in production, as the following analysis shows. Total reduction in production in the U.S. over the period 1998/2004 is of the order of 30 million tons. This is turn lead to a reduction of about 14 million tons in crushing and 14 million tons in exports of soybeans. That is, 50 percent of the effect on production influences directly exports. The 50 percent directed to additional crushing also finds its way to the world markets through more exports of soybean oil and soybean meal. Thus, this program contains an important element of export subsidy that is ignored by the current definitions adopted in the WTO.

Scenario 2. Tables 14 to 23 contain results of simulations. The results encountered in this scenario do not differ qualitatively of those found in Scenario 1. The difference in the simulation between the two is that we have included fixed payments and counter cyclical payments as if they were not decoupled. As noted before, there is clearly an impact on production and trade induced by these policies that works through an expectation mechanism induced by the fact that the 2007 farm bill is likely to allow revisions of acreage and yield and only farmers who are now producing will be eligible for the revisions. To capture this mechanism in an econometric model is not easy and not feasible since the data is not yet available. In view of this difficulty, the authors agreed to simulate the effect of the removal of these policies as if they were not decoupled. This is likely to provide an upper bound for the actual impacts of the change in policy.

It is not necessary to analyze Tables 14 to 23 in detail since the nature of the results is similar. Nevertheless, we emphasize the points below.

- World price of soybeans increase by a maximum of 9 percent in 2000 and the increase remains above 7 percent in 2001 and 2002.

- Producer prices in the U.S. are reduced 16 percent on average, with values as high as 20 percent towards the end of the period.

- Brazilian losses due to the policy can be summarized as follows: production of soybeans is reduced by almost 13 million tons during the period 1998/2004; during the same period net exports of soybeans are reduced by 9 million tons, equivalent to US $\$ 2.2$ billion; and net exports of the soybean complex are reduced by US $\$ 4$ billions. 


\section{Summary}

This paper has analyzed the impact of the current U.S. policy for soybeans on Brazilian production and trade of soybean and soybean products. The main findings of the study were:

- The elimination of the domestic support to soybeans will increase world prices of soybeans and of soybean products. The average increase in soybean prices during the period 1998/2004 varies between 4 and 5 percent according to the liberalization scenario considered. The maximum increase in prices occurs in 2000 and 2001, when the marketing loan program provided the highest levels of support.

- Brazilian production over the entire period is reduced between 10 and 13 million tons.

- Exports of soybeans are reduced between 7 and 9 million tons, equivalent to US\$ 1.6 to US $\$ 2.2$ billion.

- Exports of the soybean complex are reduced between US\$ 3 and US $\$ 4$ billion dollars.

- This domestic support provided by U.S. policy has a significant impact on trade, since about 50 percent of the increase in soybean production will be exported directly. But the total impact is even greater since exports of soybean meal and soybean oil will take place too.

In conclusion this subsidy is causing damage to Brazilian producers and exporters. Governmental initiatives leading to the elimination of this type of support are important not only because of the estimated impacts but because these policies are likely to continue and cumulative effects can cause distress in the sector, with reductions in income and employment. 


\section{Tables}

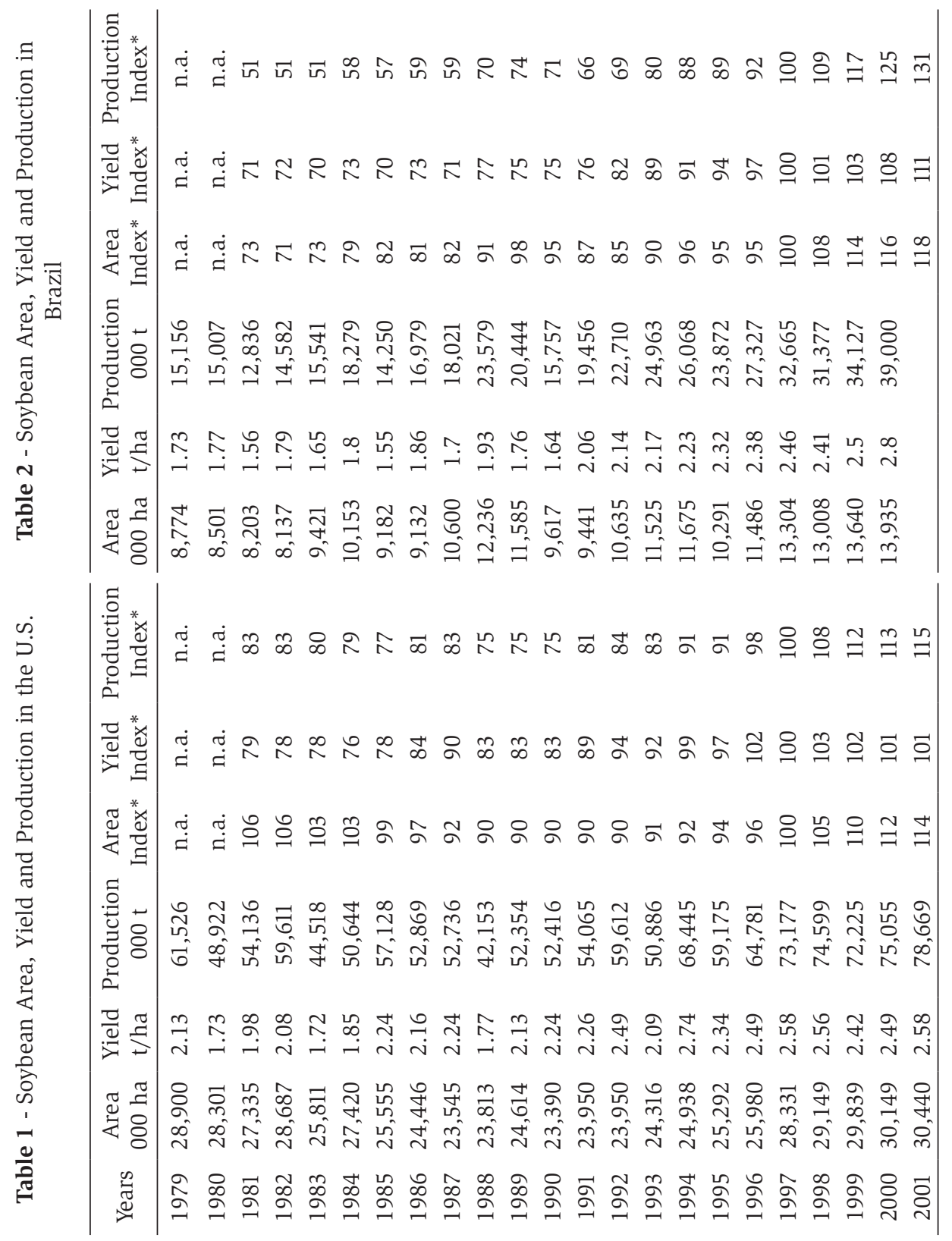

Source: Oil World

* Based on three year average 

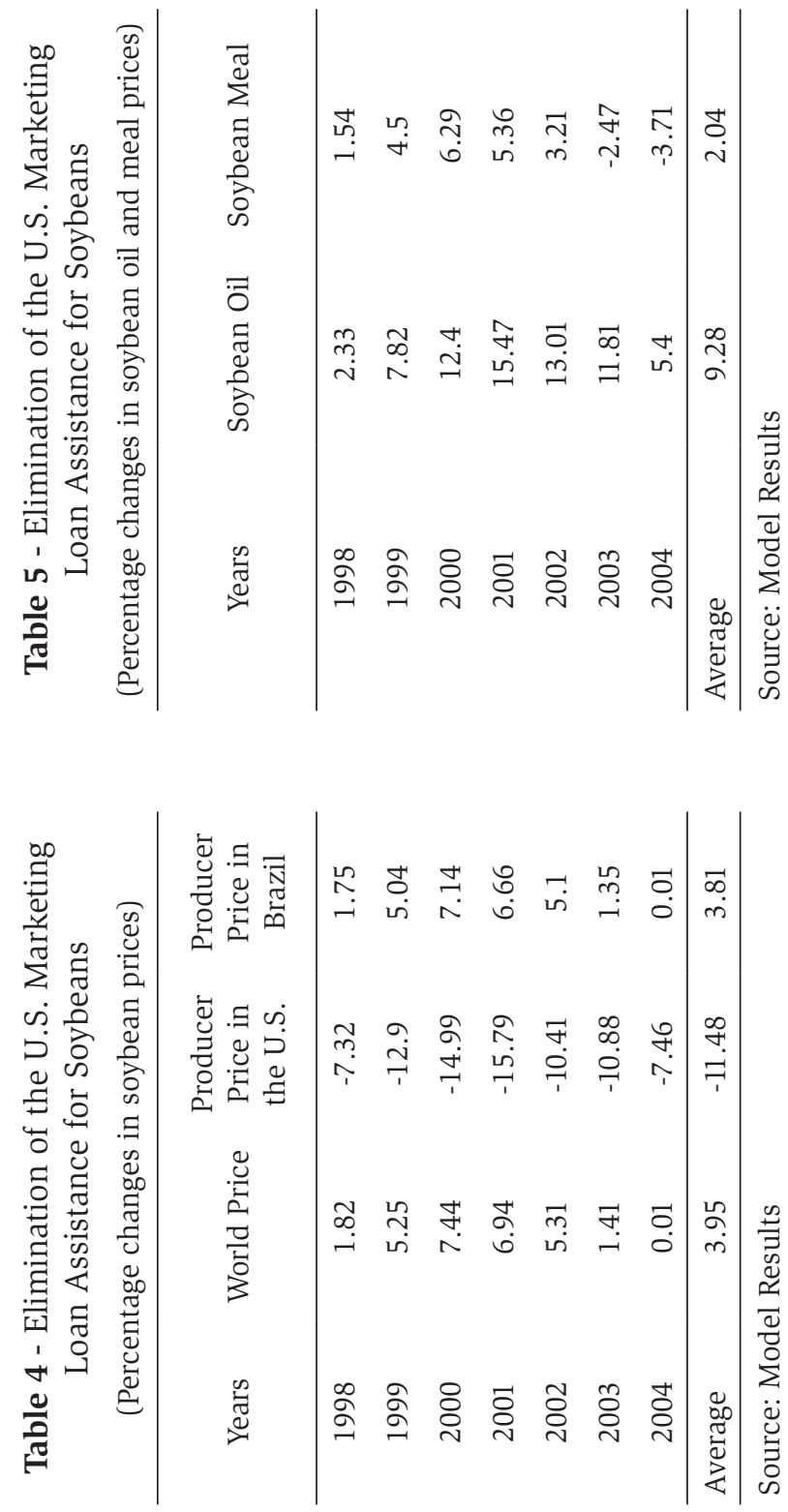

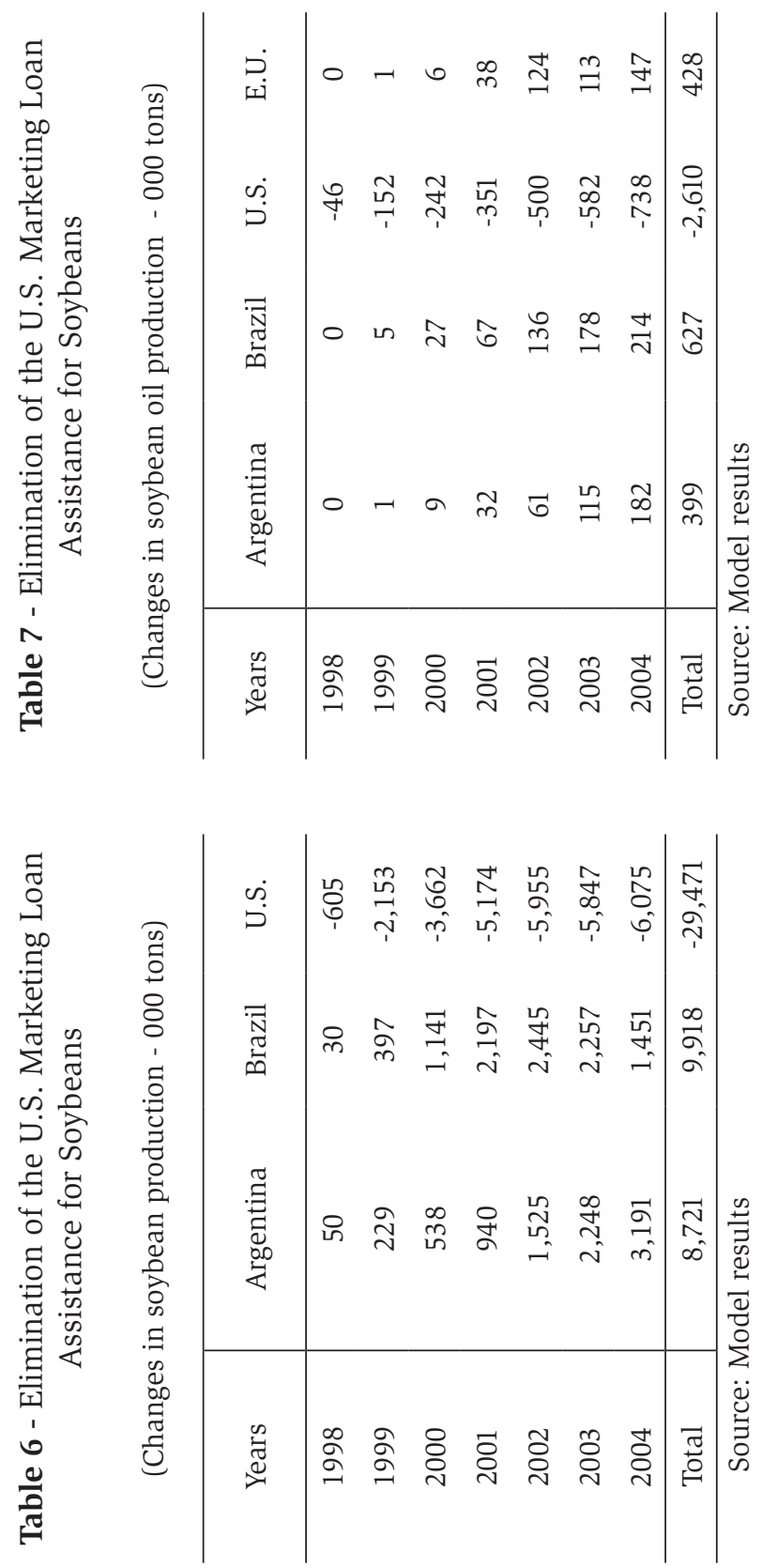

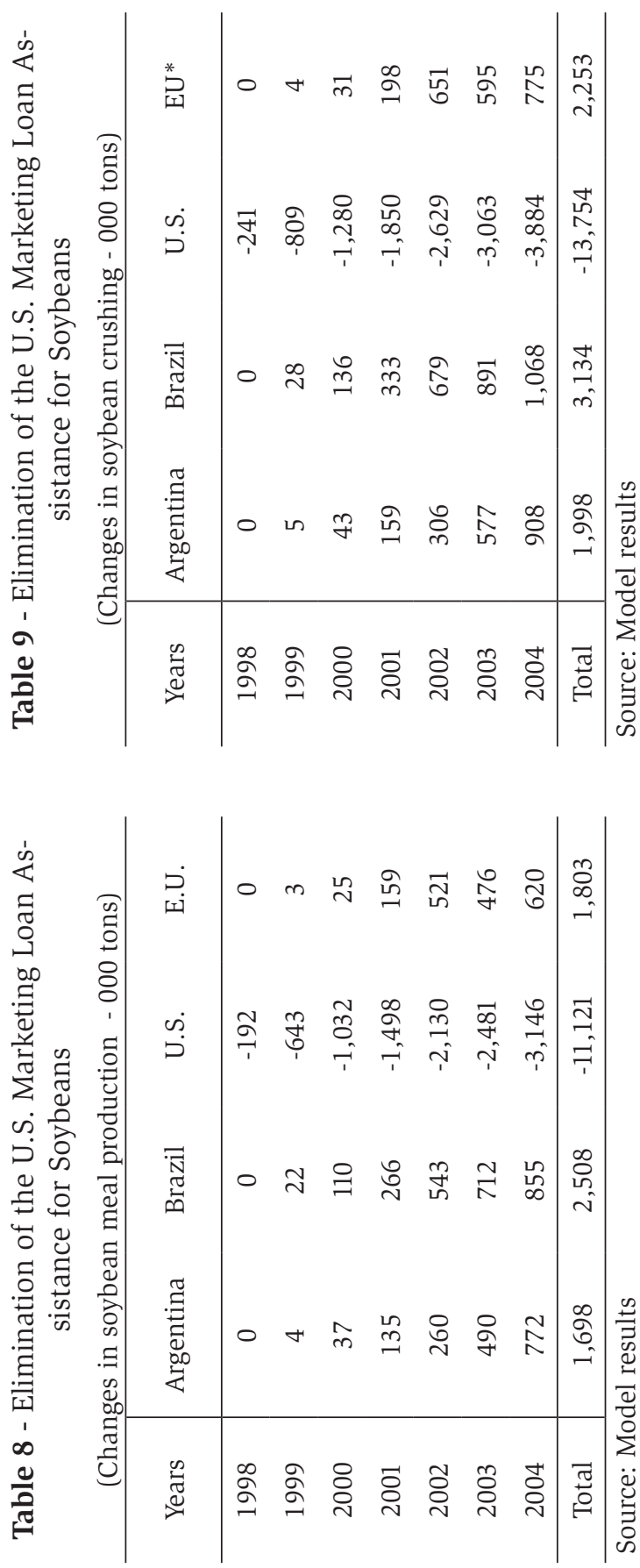

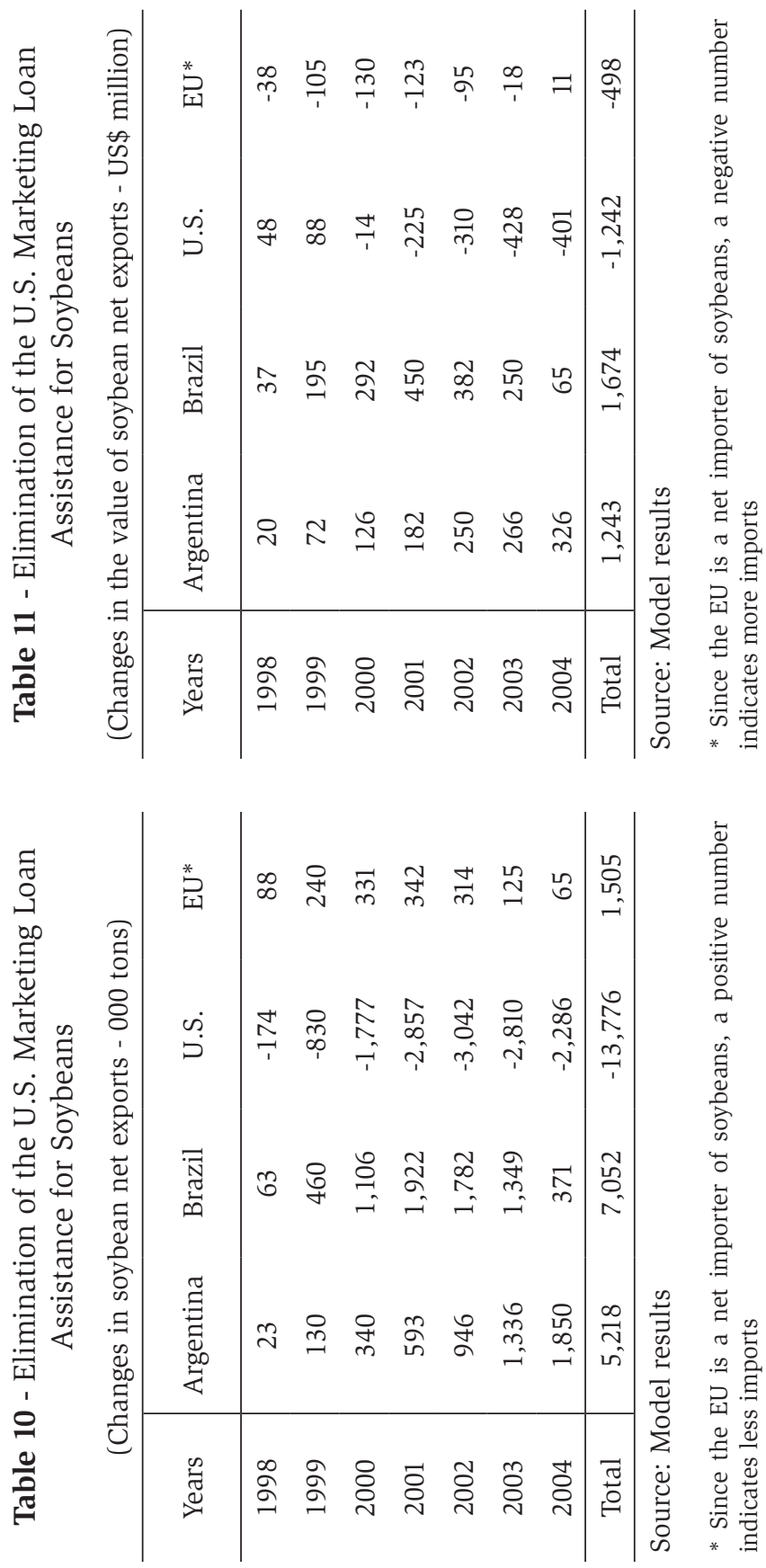

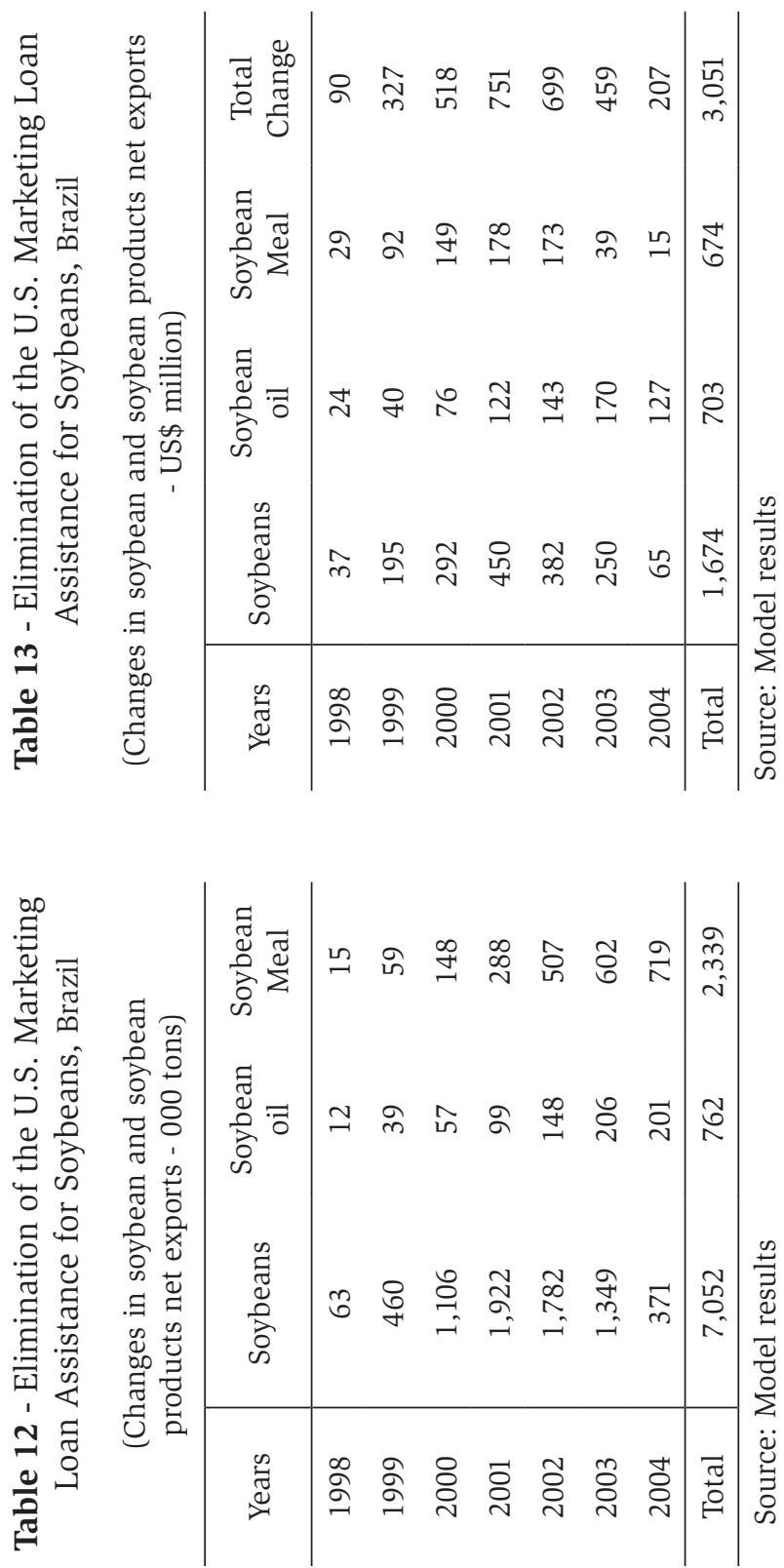

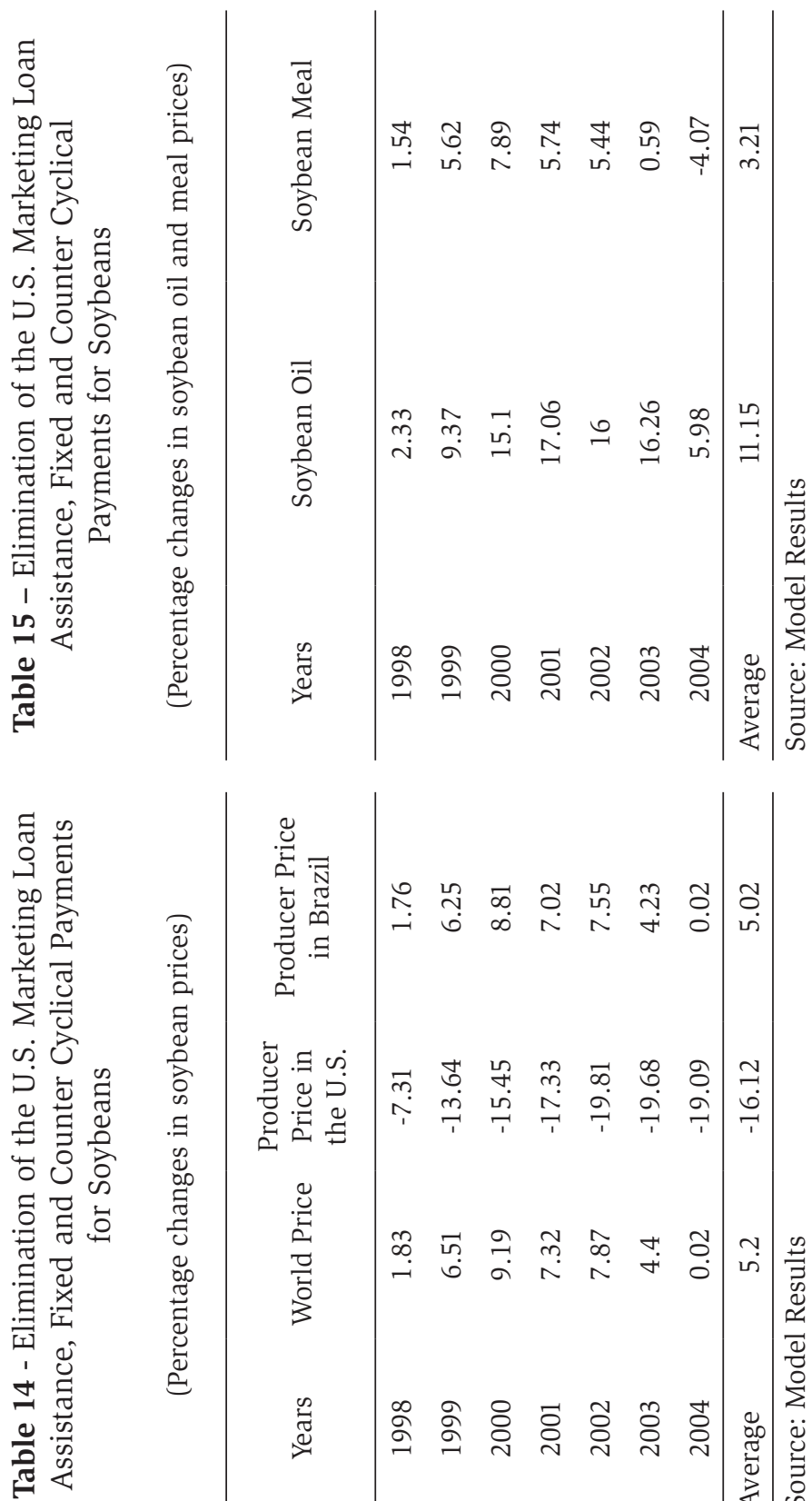

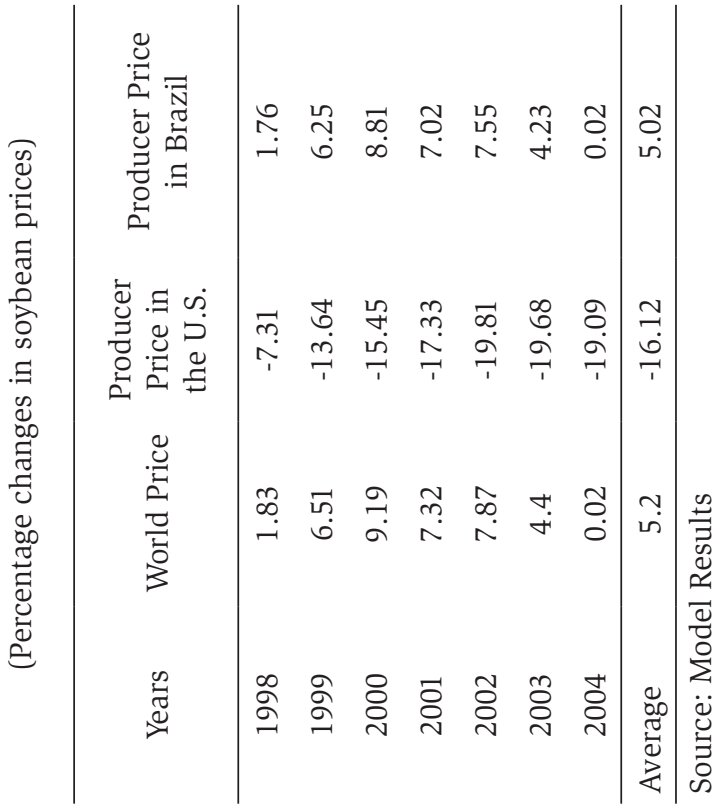



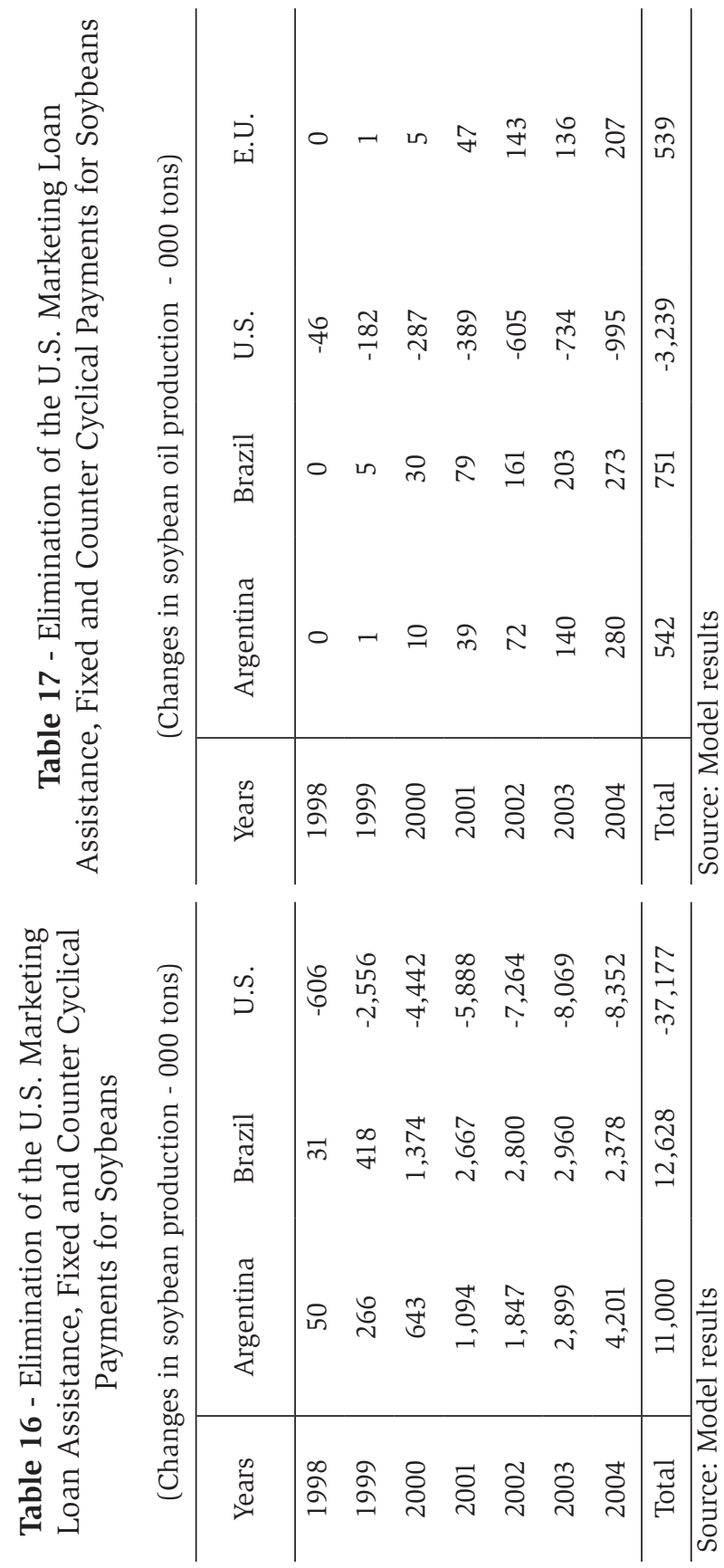


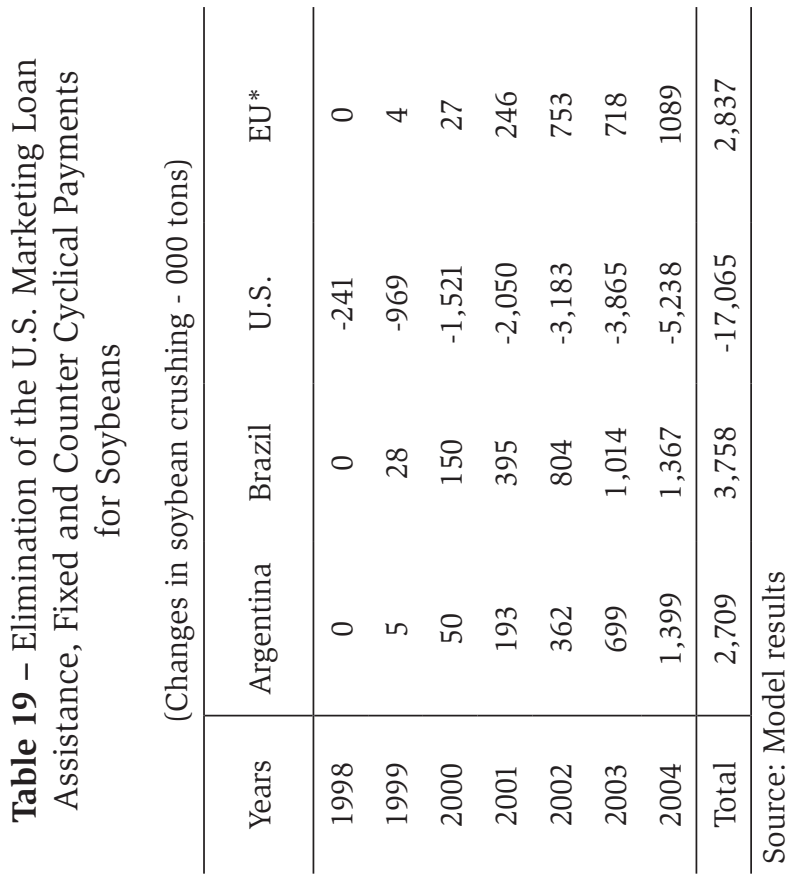

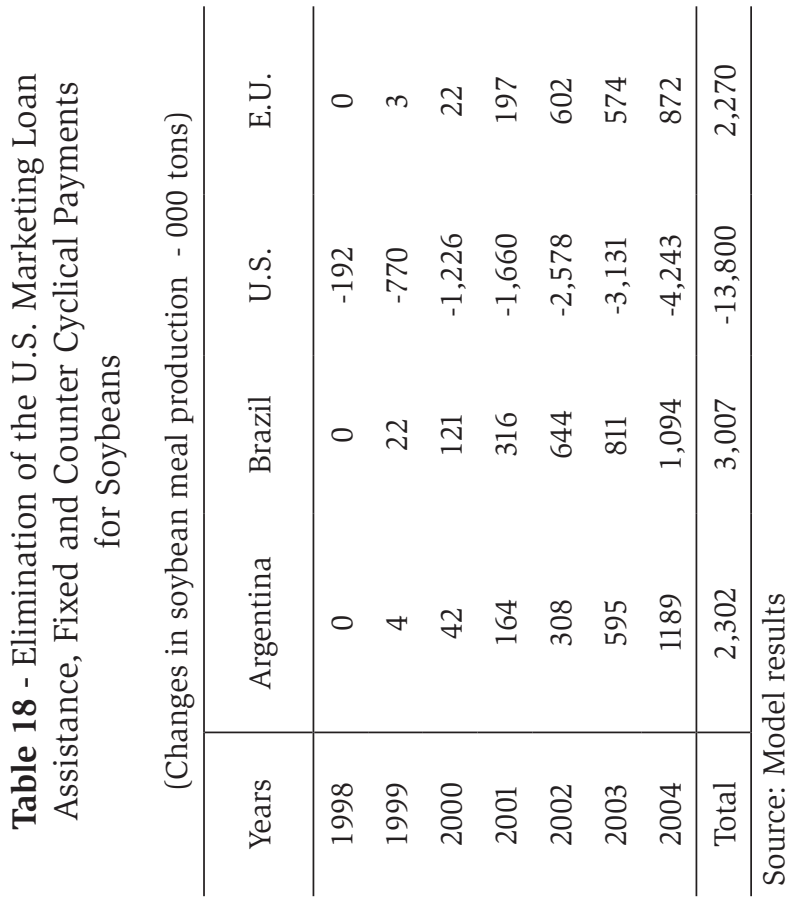




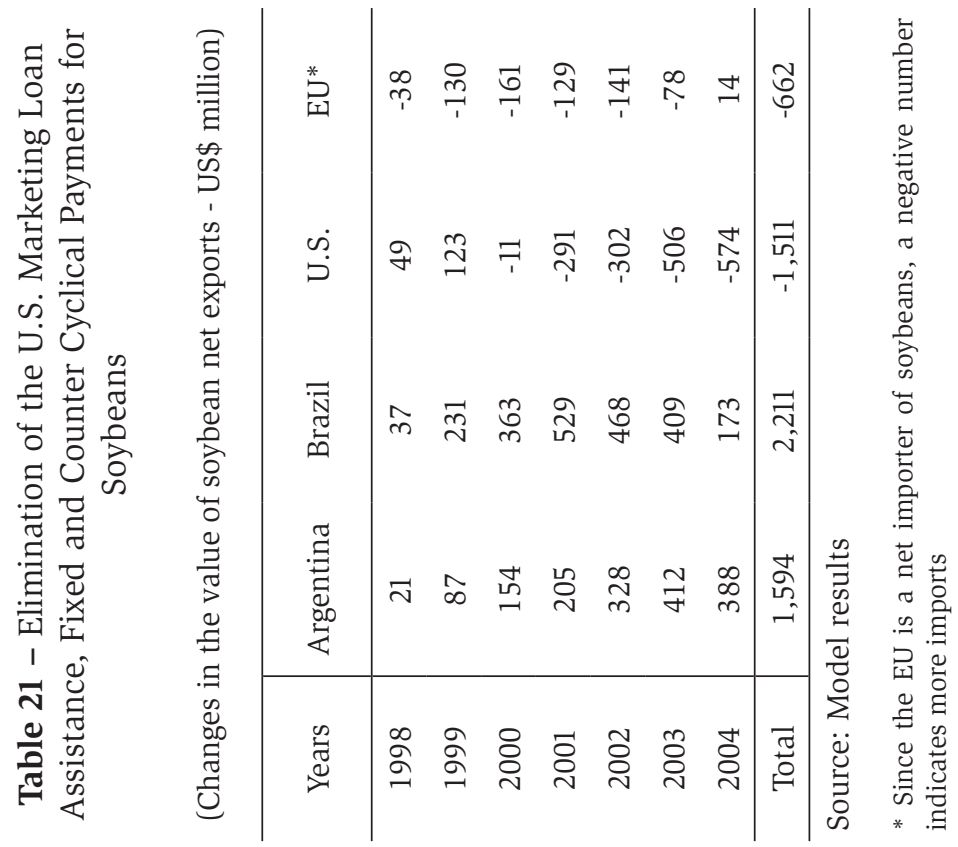

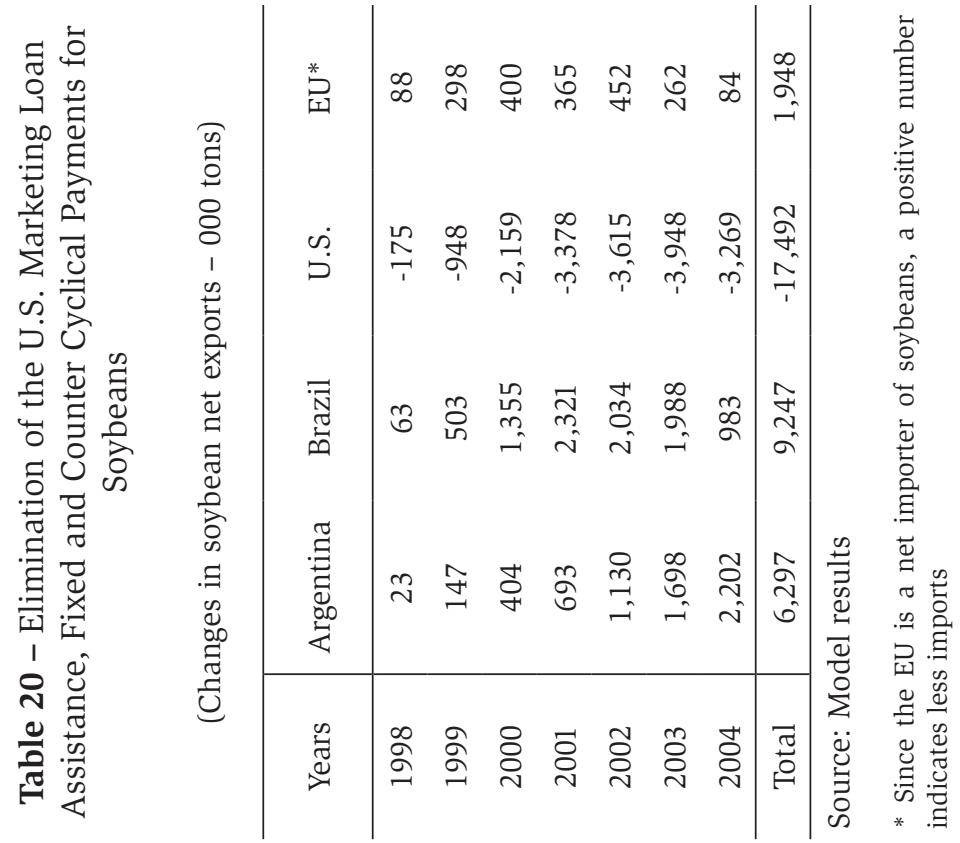




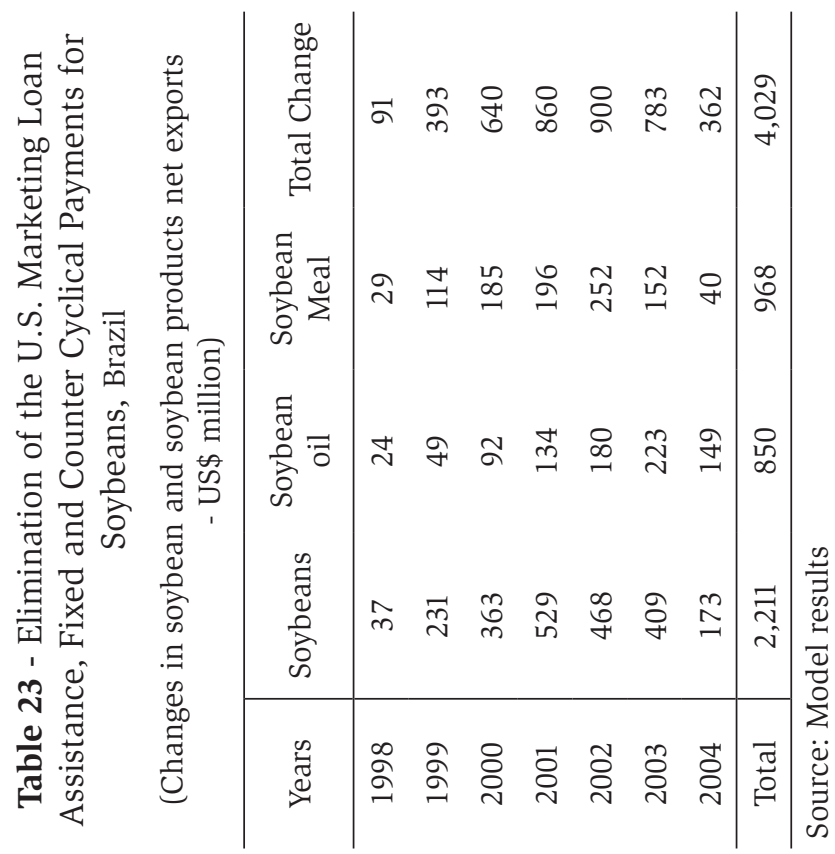

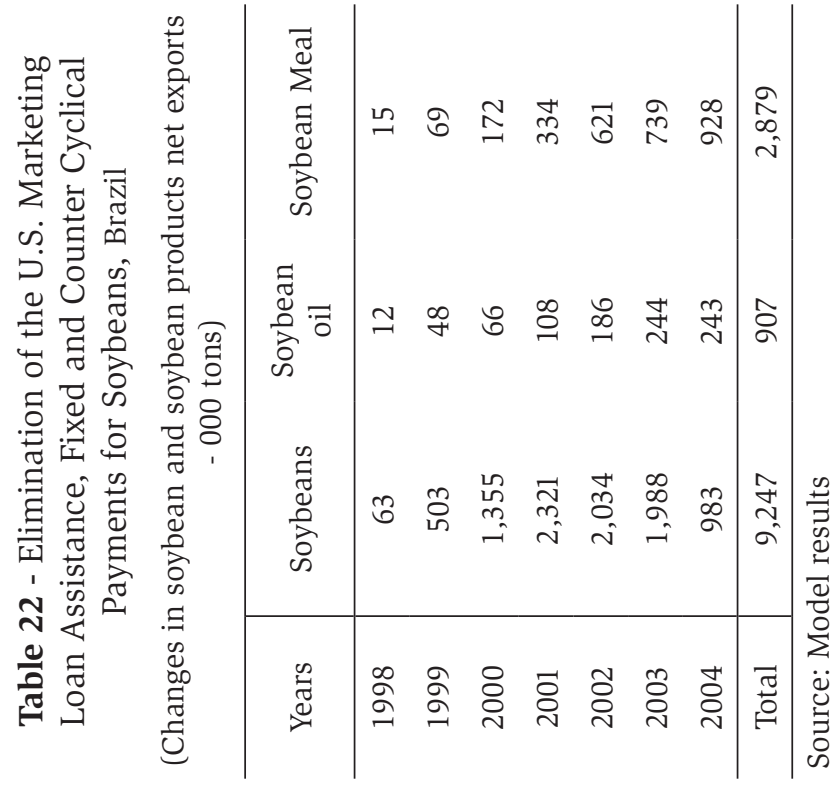




\section{References}

Hart, Charles E. and Bruce A. Babcock. Implications of the WTO on the Redesign of U.S. Farm Policy. Center for Agricultural and Rural Development, Iowa State University, Briefing Paper 01-BP 32, May 2001.

Nelson, Frederick J. Aligning U.S. Farm Policy with World Trade Commitments, Agricultural Outlook, January - February 2002, pp. 12-16.

OECD Agricultural Outlook 2000-2005, Paris, 2000.

OECD Agricultural Outlook 2001-2006, Paris, 2001.

OECD Agricultural Policies in OECD Countries: Monitoring and Evaluation, Paris, 2001.

OECD Agricultural Databases, CD, Paris 2001.

Orden, David. Reform's Stunted Crop, in Regulation, Spring 2002, Vol. $25, \mathrm{~N}^{\circ} 1$.

Scronce, Philip W. Grains and Oilseeds Outlook for 2001. Feed Grains and Oilseeds Analysis Group, Farm Service Agency, U.S. Department of Agriculture. Agricultural Outlook Forum 2001, February 23, 2001.

USDA Agricultural Statistics 2001, CD, Washington, D.C., 2001

Valdés, Alberto and William Foster. Reflections on the Policy Implications of Agricultural Price Distortions and Price Transmission for Producers in Developing Countries and Transition Economies. Paper presented at the OECD Global Forum on Agriculture, OECD, Paris, May 23 and 24, 2002.

Westcott, Paul and Michael J. Price. Analysis of the U.S. Commodity Loan Program with Commodity Loan Provisions. Economic Research Service/USDA, Agricultural Economic Report No. 801, April 2001.

Westcott, Paul C. and Michael J. Price. Impacts of the U.S. Marketing Loan Program for Soybeans. Special Article for Oil Crops Situation and Outlook, Economic Research Service/USDA, October 1999, pp. 15-21. 


\section{Annex I - Equations}

\section{Argentina Module}

\section{Table 24}

Other uses

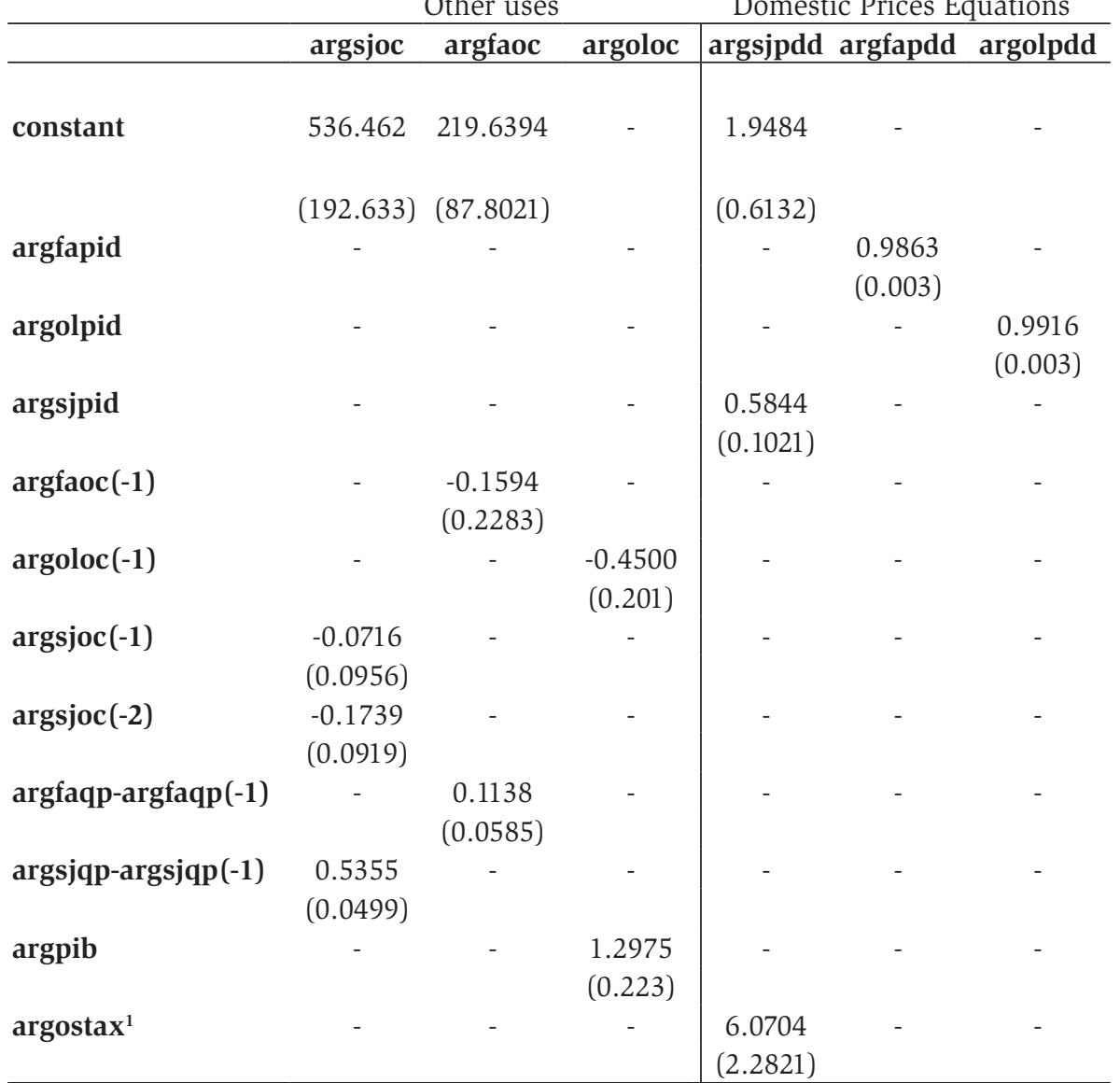

${ }^{1}$ Not logarithm 


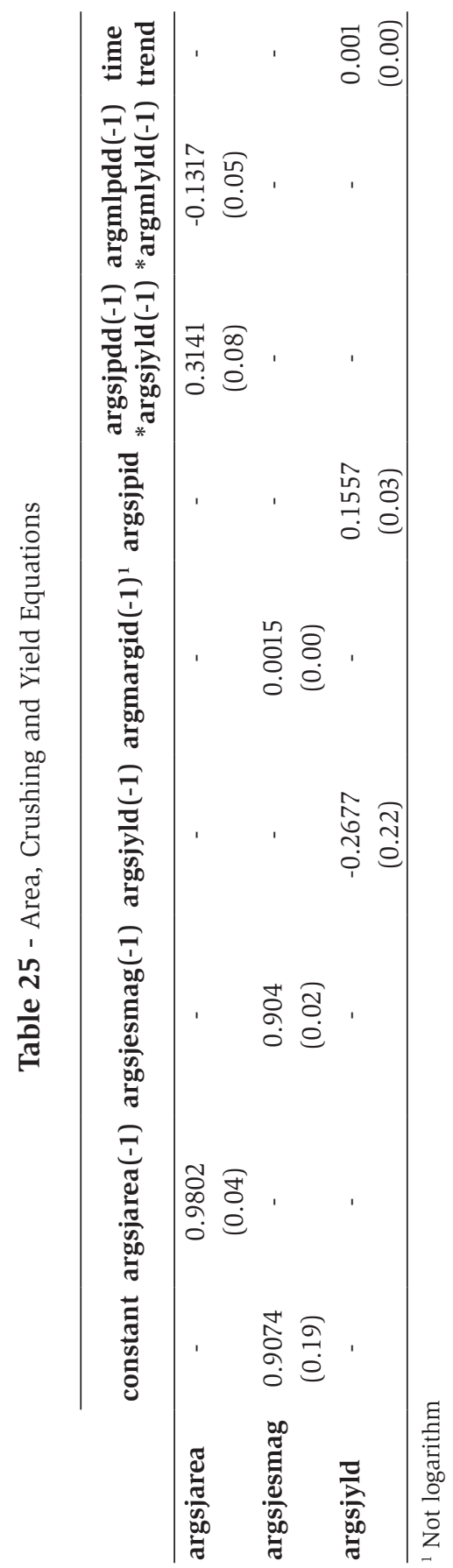




\section{Brazil Module}

Table 26

\begin{tabular}{|c|c|c|c|c|c|c|}
\hline & \multirow{2}{*}{$\frac{\text { Net Exports }}{\text { brfaexl }}$} & \multicolumn{2}{|c|}{ Other Uses } & \multicolumn{3}{|c|}{ Domestic Prices Equations } \\
\hline & & brsjoc $^{1}$ & broloc & brsjpdd & brfapdd & brolpdd \\
\hline constant & - & $\begin{array}{c}6364 \\
(1904)\end{array}$ & - & - & $\begin{array}{l}-0.7506 \\
(0.3510)\end{array}$ & $\begin{array}{l}0.8012 \\
(0.5024)\end{array}$ \\
\hline brfapid & $\begin{array}{c}0.0896 \\
(0.0295)\end{array}$ & - & - & - & $\begin{array}{c}1.1229 \\
(0.0550)\end{array}$ & - \\
\hline brolpid & - & - & $\begin{array}{l}-0.2028 \\
(0.1104)\end{array}$ & - & - & $\begin{array}{c}1.1251 \\
(0.0690)\end{array}$ \\
\hline brsjpid $^{1}$ & - & $\begin{array}{l}-4.1606 \\
(2.1230)\end{array}$ & - & - & - & - \\
\hline brsjpid & - & - & - & $\begin{array}{c}0.9610 \\
(0.0021)\end{array}$ & - & - \\
\hline brfaqp & $\begin{array}{c}1.2141 \\
(0.0909)\end{array}$ & - & - & - & - & - \\
\hline brsuqp & $\begin{array}{l}-0.1744 \\
(0.0886)\end{array}$ & - & - & - & - & - \\
\hline brfaexl(-1) & $\begin{array}{c}0.1010 \\
(0.0637)\end{array}$ & - & - & - & - & - \\
\hline $\operatorname{broloc}(-1)$ & - & - & $\begin{array}{c}-0.9777 \\
(0.3400)\end{array}$ & - & - & - \\
\hline broloc $(-2)$ & - & - & $\begin{array}{c}-0.6911 \\
(0.3405)\end{array}$ & - & - & - \\
\hline $\operatorname{broloc}(-3)$ & - & - & $\begin{array}{l}-0.3934 \\
(0.2763)\end{array}$ & - & - & - \\
\hline brfrango & $\begin{array}{l}-0.1766 \\
(0.0649)\end{array}$ & - & - & - & - & - \\
\hline brpop & - & - & $\begin{array}{c}1.2673 \\
(0.3475)\end{array}$ & - & - & - \\
\hline brtjur $^{1}$ & - & $\begin{array}{c}-65.9313 \\
(37.5900)\end{array}$ & - & - & - & - \\
\hline $\operatorname{brsjoc}(-2)^{1}$ & - & $\begin{array}{l}-0.7322 \\
(0.2354)\end{array}$ & - & - & - & - \\
\hline time trend & & & $\begin{array}{c}0.0834 \\
(0.0233)\end{array}$ & & & \\
\hline dummy & - & - & & $\begin{array}{c}0.0832 \\
(0.0291)\end{array}$ & $\begin{array}{c}0.0479 \\
(0.0390)\end{array}$ & $\begin{array}{c}0.1547 \\
(0.0552)\end{array}$ \\
\hline
\end{tabular}

${ }^{1}$ Not logarithm 
664 Impacts of the U.S. subsidy to soybeans on World prices, production and exports

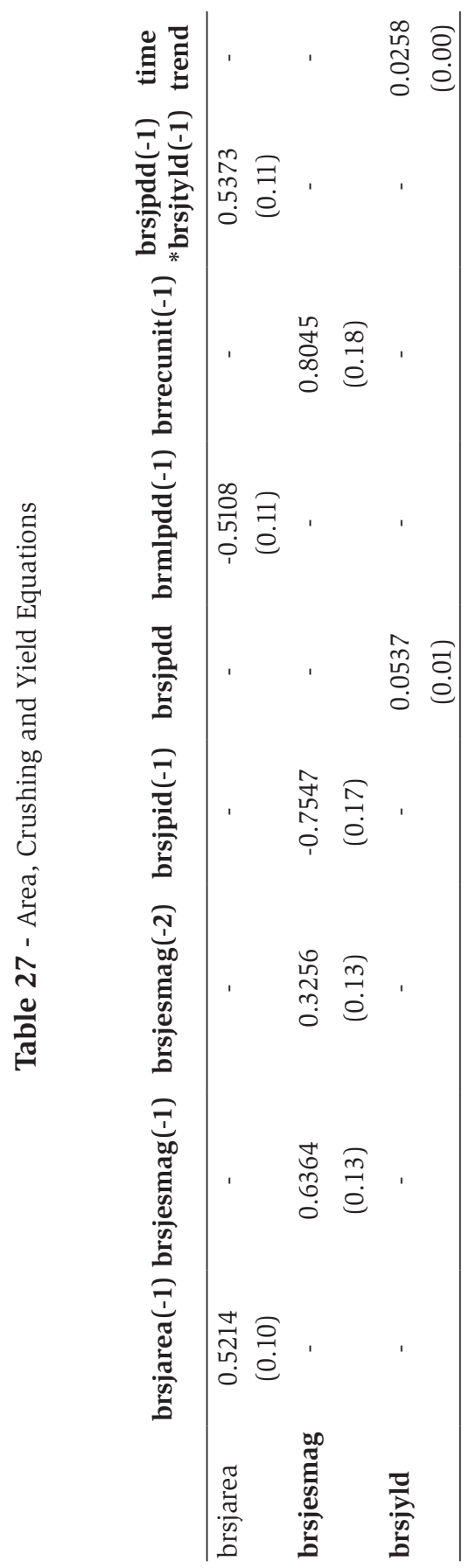

RER, Rio de Janeiro, vol. 44, no 04, p. 631-676, out/dez 2006 - Impressa em dezembro 2006 


\section{European Union Module}

Table 28

Net Exports Equations

Domestic Prices Equations

\begin{tabular}{|c|c|c|c|c|c|c|}
\hline & cesjiml & cefaiml & ceolexl & cesjpdd $^{1}$ & cefapdd & ceolpdd $^{1}$ \\
\hline constant & $\begin{array}{c}10.0482 \\
(4.1985)\end{array}$ & - & - & $\begin{array}{l}684.1700 \\
(45.3229)\end{array}$ & - & - \\
\hline cefapid & - & $\begin{array}{l}-0.2940 \\
(0.1002)\end{array}$ & - & - & $\begin{array}{c}1.1336 \\
(0.1144)\end{array}$ & - \\
\hline cefapid(-1) & - & - & - & - & $\begin{array}{l}-0.1227 \\
(0.1137)\end{array}$ & - \\
\hline ceolpid & - & - & $\begin{array}{c}0.2100 \\
(0.0536)\end{array}$ & - & - & \\
\hline ceolpid $^{1}$ & - & - & & - & - & $\begin{array}{c}1.2888 \\
(0.1027)\end{array}$ \\
\hline ceolpid $(-1)^{1}$ & - & - & - & - & - & $\begin{array}{c}-0.7004 \\
(0.1678)\end{array}$ \\
\hline cesjpid $^{1}$ & - & - & - & $\begin{array}{c}0.4707 \\
(0.1076)\end{array}$ & - & - \\
\hline ceolpdd $(-1)^{1}$ & - & - & - & - & - & $\begin{array}{c}0.4377 \\
(0.1747)\end{array}$ \\
\hline ceolqp ${ }^{1}$ & - & - & $\begin{array}{c}0.0010 \\
(0.0001)\end{array}$ & - & - & - \\
\hline ceruqp & - & $\begin{array}{c}0.4672 \\
(0.1506)\end{array}$ & - & - & - & - \\
\hline cefaiml(-1) & - & $\begin{array}{c}0.5666 \\
(0.1489)\end{array}$ & - & - & - & - \\
\hline cesjiml(-1) & $\begin{array}{l}-0.1220 \\
(0.2864)\end{array}$ & - & - & - & - & - \\
\hline cesjiml(-2) & $\begin{array}{c}0.2527 \\
(0.2687)\end{array}$ & - & - & - & - & - \\
\hline $\operatorname{ceolexl}(-2)$ & - & - & $\begin{array}{c}0.4060 \\
(0.0748)\end{array}$ & - & - & - \\
\hline cesjtcr*misjpid & $\begin{array}{l}-0.3084 \\
(0.1514)\end{array}$ & - & - & - & - & - \\
\hline dummy & - & - & - & $\begin{array}{l}-543.8232 \\
(29.2943)\end{array}$ & - & - \\
\hline
\end{tabular}

${ }^{1}$ Not logarithm 
666 Impacts of the U.S. subsidy to soybeans on World prices, production and exports

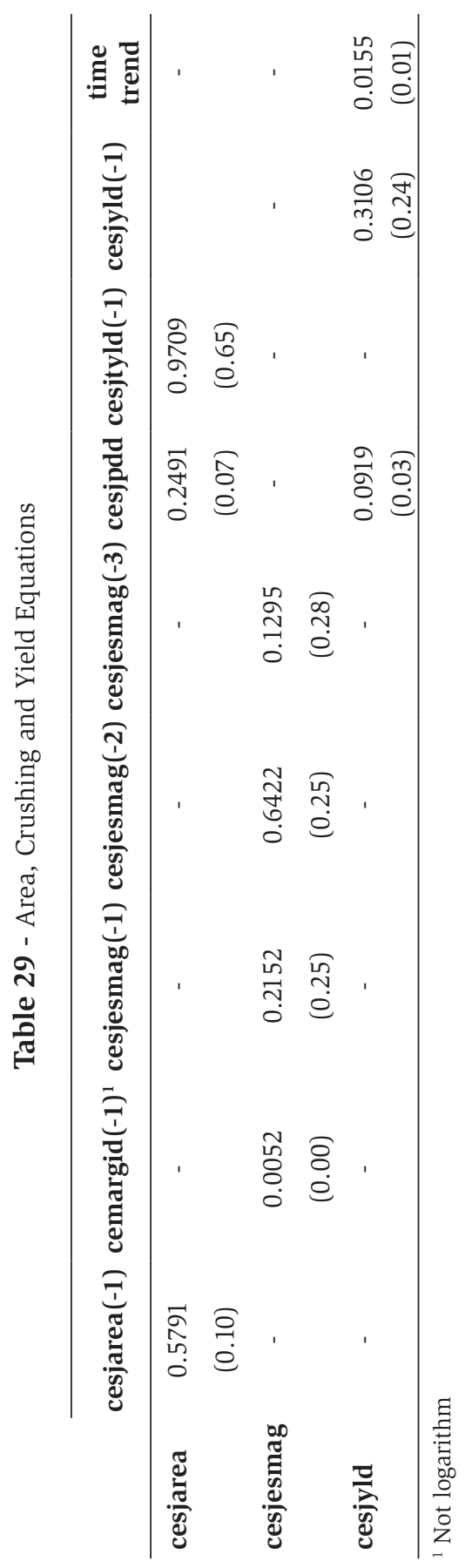

RER, Rio de Janeiro, vol. 44, no 04, p. 631-676, out/dez 2006 - Impressa em dezembro 2006 
U.S. Module

Table 30

\begin{tabular}{|c|c|c|c|c|c|c|}
\hline & \multirow{2}{*}{$\begin{array}{c}\text { Net Exports } \\
\text { euafaexl } \\
\end{array}$} & \multicolumn{2}{|c|}{ Other Uses } & \multicolumn{3}{|c|}{ Domestic Prices Equations } \\
\hline & & euasjoc $^{1}$ & euaoloc & euasjpdd & euafapdd $^{1}$ & euaolpdd \\
\hline constant & $\begin{array}{r}-20.4383 \\
(4.0171)\end{array}$ & $\begin{array}{l}18567 \\
(3516)\end{array}$ & $\begin{array}{l}11.7932 \\
(1.4781)\end{array}$ & $\begin{array}{l}-0.0749 \\
(0.1922)\end{array}$ & - & $\begin{array}{c}-0.6092 \\
(0.2352)\end{array}$ \\
\hline euafapid & $\begin{array}{c}0.2136 \\
(0.1062)\end{array}$ & - & - & - & - & - \\
\hline euafapid $^{1}$ & - & - & - & - & $\begin{array}{c}1.0354 \\
(0.0405)\end{array}$ & - \\
\hline euaolpid & - & - & $\begin{array}{l}-0.1754 \\
(0.0494)\end{array}$ & - & - & $\begin{array}{c}1.0965 \\
(0.0373)\end{array}$ \\
\hline euasjpid ${ }^{1}$ & - & $\begin{array}{l}-54.9704 \\
(12.9759)\end{array}$ & - & - & - & - \\
\hline euasjpid & - & - & - & $\begin{array}{c}1.0073 \\
(0.0346)\end{array}$ & - & - \\
\hline euafapdd $(-1)^{1}$ & - & - & - & - & $\begin{array}{l}-0.0485 \\
(0.0396)\end{array}$ & - \\
\hline euafaqp & $\begin{array}{c}2.9342 \\
(0.3850)\end{array}$ & - & - & - & - & - \\
\hline euafaexl(-2) & $\begin{array}{l}-0.1391 \\
(0.1069)\end{array}$ & - & - & - & - & - \\
\hline euaoloc $(-2)$ & - & - & $\begin{array}{l}-0.2946 \\
(0.1683)\end{array}$ & - & - & - \\
\hline euasjoc $(-2)^{1}$ & - & $\begin{array}{l}-0.3379 \\
(0.1692)\end{array}$ & - & - & - & - \\
\hline dummy & - & - & - & - & $\begin{array}{l}-11.1343 \\
(2.9906)\end{array}$ & - \\
\hline time trend & $\begin{array}{l}-0.0641 \\
(0.0105)\end{array}$ & - & $\begin{array}{c}0.0367 \\
(0.0049)\end{array}$ & - & - & - \\
\hline
\end{tabular}

${ }^{1}$ Not logarithm 


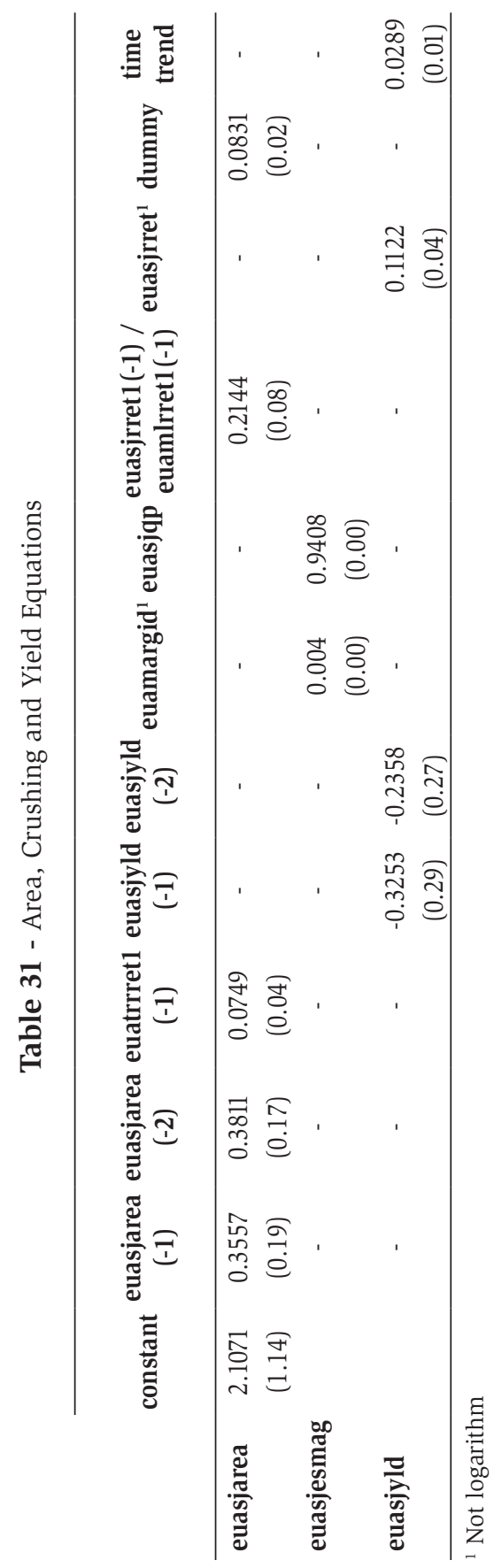



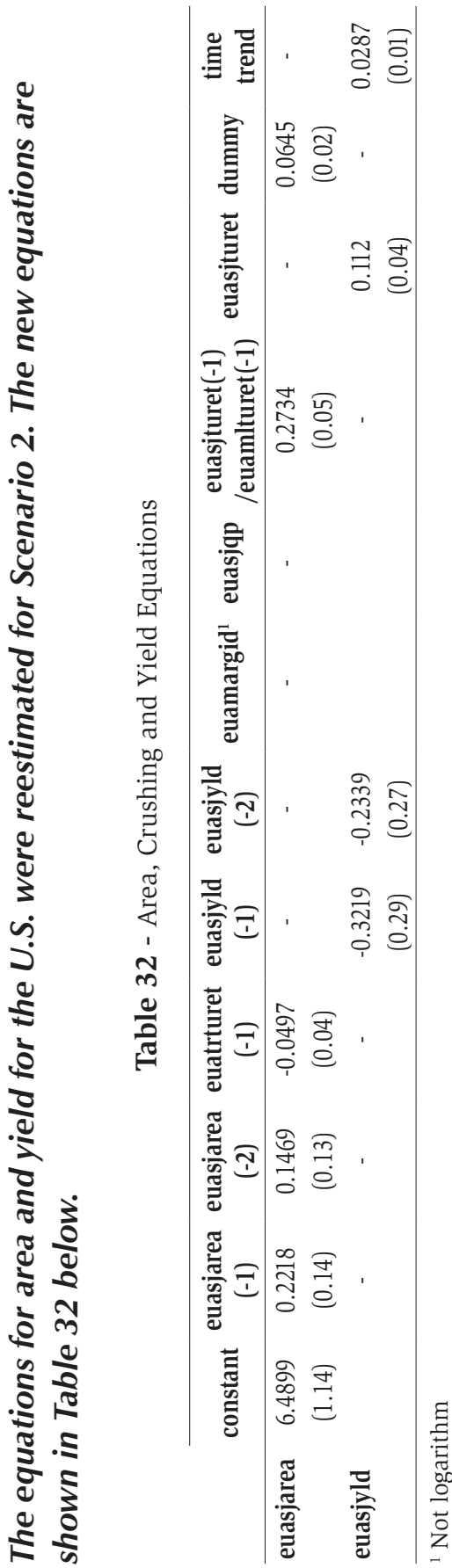

RER, Rio de Janeiro, vol. 44, no 04, p. 631-676, out/dez 2006 - Impressa em dezembro 2006 


\title{
10. Annex II - Notation
}

\author{
Argentine Module \\ argfaoc soybean meal other uses, 1000 ton, calculation. \\ argfapdd soybean meal domestic price, Pesos/ton, \\ MECON/SAGPyA. \\ argfapid soybean meal international price, Pesos/ton, CBOT. \\ argfaqp soybean meal production, 1000 ton, OIL WORLD. \\ argmargid crushing margin at international prices \\ argmlpdd maize domestic price, pesos/ton, MECON/SAGPyA. \\ argmlyld maize yield, kg/ha. \\ argoloc soybean oil other uses,1000 ton, calculation. \\ argolpdd soybean oil domestic price, Pesos/ton, MECON/SAGPyA. \\ argolpid soybean oil international price, Pesos/ton, CBOT. \\ argostax oil seed tax rate \\ argpib gross domestic product, FMI/IFS - International. \\ argsjoc soybean other uses, 1000 ton, calculation. \\ argsjarea soybean area planted, 1000 ha, MECON. \\ argsjesmag soybean crushing, 1000 ton, OIL WORLD. \\ argsjpdd soybean domestic price, Pesos/ton, MECON/SAGPyA. \\ argsjpid soybean international price, Pesos/ton, CBOT. \\ argsjyld soybean yield ton/ha, MECON.
}

\section{Brazilian Module}

brfaexl soybean meal net exports, 1000 ton, OIL WORLD.

brfapdd soybean meal domestic price, R\$/ton, DERAL/DEB - SEAB/PR.

brfapid soybean meal international price, R\$/ton, CBOT.

brfaqp soybean meal production 1000 ton, OIL WORLD.

brfrango chicken meat production 1000 ton, UBA / APINCO.

brmlpdd maize domestic price, R\$/ton, FGV.

broloc soybean oil other uses,1000 ton, calculation.

brolpdd soybean oil domestic price, R $\$$ /ton, DERAL/DEB - SEAB/PR. 


$\begin{array}{ll}\text { brolpid } & \text { soybean oil international price, R\$/ton, CBOT. } \\ \text { brpop } & \text { population estimated, IBGE. } \\ \text { brrecunit } & \text { unitary revenue from crushing } \\ \text { brsjarea } & \text { soybean area planted, 1000 ha, IBGE. } \\ \text { brsjesmag } & \text { soybean crushing, 1000 ton, OIL WORLD. } \\ \text { brsjoc } & \text { soybean other uses,1000 ton, calculation. } \\ \text { brsjpdd } & \text { soybean domestic price, R\$/ton, FGV. } \\ \text { brsjpid } & \text { soybean international price, R\$/ton, CBOT. } \\ \text { brtjur } & \text { real interest rate. } \\ \text { brsjyld } & \text { soybean yield ton/ha, IBGE. } \\ \text { brsuqp } & \text { pork production } 1000 \text { ton, IBGE. }\end{array}$

\section{U.S. Module}

euafaexl soybean meal net exports, 1000 ton, OIL WORLD.

euafapdd soybean meal domestic price, US\$/ton, USDA.

euafapid soybean meal international price, US\$/ton, CBOT.

euafaqp soybean meal production 1000 ton, OIL WORLD.

euamlrret1 farm return for corn producers

euamargid crushing margin at international prices

euaoloc soybean oil other uses,1000 ton, calculation.

euaolpdd soybean oil domestic price, US\$/ton, USDA.

euaolpid soybean oil international price, US\$/ton, CBOT.

euatrplr loan rate for wheat

euasjarea soybean area planted, 1000 ha, USDA.

euasjesmag soybean crushing, 1000 ton, OIL WORLD.

euasjoc soybean other uses,1000 ton, calculation.

euasjpdd soybean domestic price, US\$/ton, USDA.

euasjpid soybean international price, US\$/ton, CBOT.

euasjqp soybean production 1000 ton, OIL WORLD.

euasjrret1 soybean farmer return

euasjyld soybean yield ton/ha, USDA. 
euasjturet price paid to the soybean producer (includes subsidies, marketing loan assistance, direct payment and counter cyclical payment), calculation

euatrturet price paid to the wheat producer (includes subsidies, marketing loan assistance, direct payment and counter cyclical payment), calculation

euamlturet price paid to the maize producer (includes subsidies, marketing loan assistance, direct payment and counter cyclical payment), calculation

\section{European Union Module}

$\begin{array}{ll}\text { cefaiml } & \text { soybean meal net imports, 1000 ton, OIL WORLD. } \\ \text { cefapdd } & \text { soybean meal domestic price, Euro/ton, AgLink } \\ \text { cefapid } & \text { soybean meal international price, Euro/ton, AgLink } \\ \text { cemargid } & \text { crushing margin at international prices } \\ \text { ceolexl } & \text { soybean oil net exports,1000 ton, OIL WORLD. } \\ \text { ceolpdd } & \text { soybean oil domestic price, Euro/ton, AgLink } \\ \text { ceolpid } & \text { soybean oil international price, Euro/ton, AgLink } \\ \text { ceolqp } & \text { soybean oil production 1000 ton, AgLink } \\ \text { cesjarea } & \text { soybean area planted, 1000 ha, AgLink } \\ \text { cesjesmag } & \text { soybean crushing, 1000 ton, OIL WORLD. } \\ \text { cesjiml } & \text { soybean net imports, 1000 ton, OIL WORLD. } \\ \text { cesjpdd } & \text { soybean domestic price, Euro/ton, AgLink } \\ \text { cesjpid } & \text { soybean international price, Euro/ton. } \\ \text { ceruqp } & \text { ruminant production 1000 ton, AgLink } \\ \text { cesjyld } & \text { soybean yield ton/ha, AgLink } \\ \text { cesjtcr } & \text { soybean farm return } \\ \text { cesjtyld } & \text { soybean yield trend, calculation. } \\ \text { misjpid } & \text { soybean international market price Euro/ton, calculation. } \\ \text { ceuatrrret1 } & \text { price paid to the wheat producer (includes subsidies: marke- } \\ & \text { ting loan assistance), calculation }\end{array}$




\section{Annex III - Model structure}

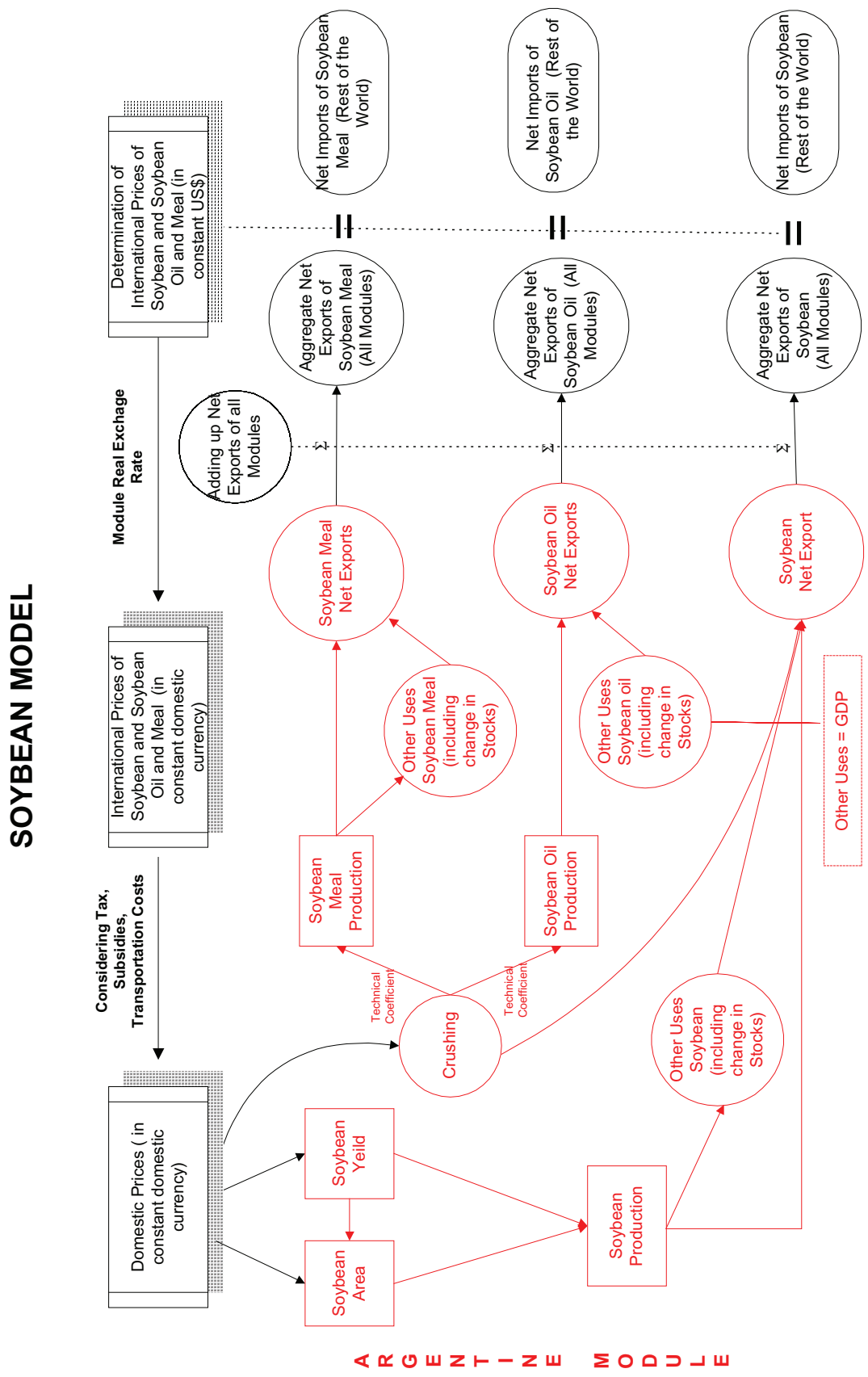

RER, Rio de Janeiro, vol. 44, no 04, p. 631-676, out/dez 2006 - Impressa em dezembro 2006 


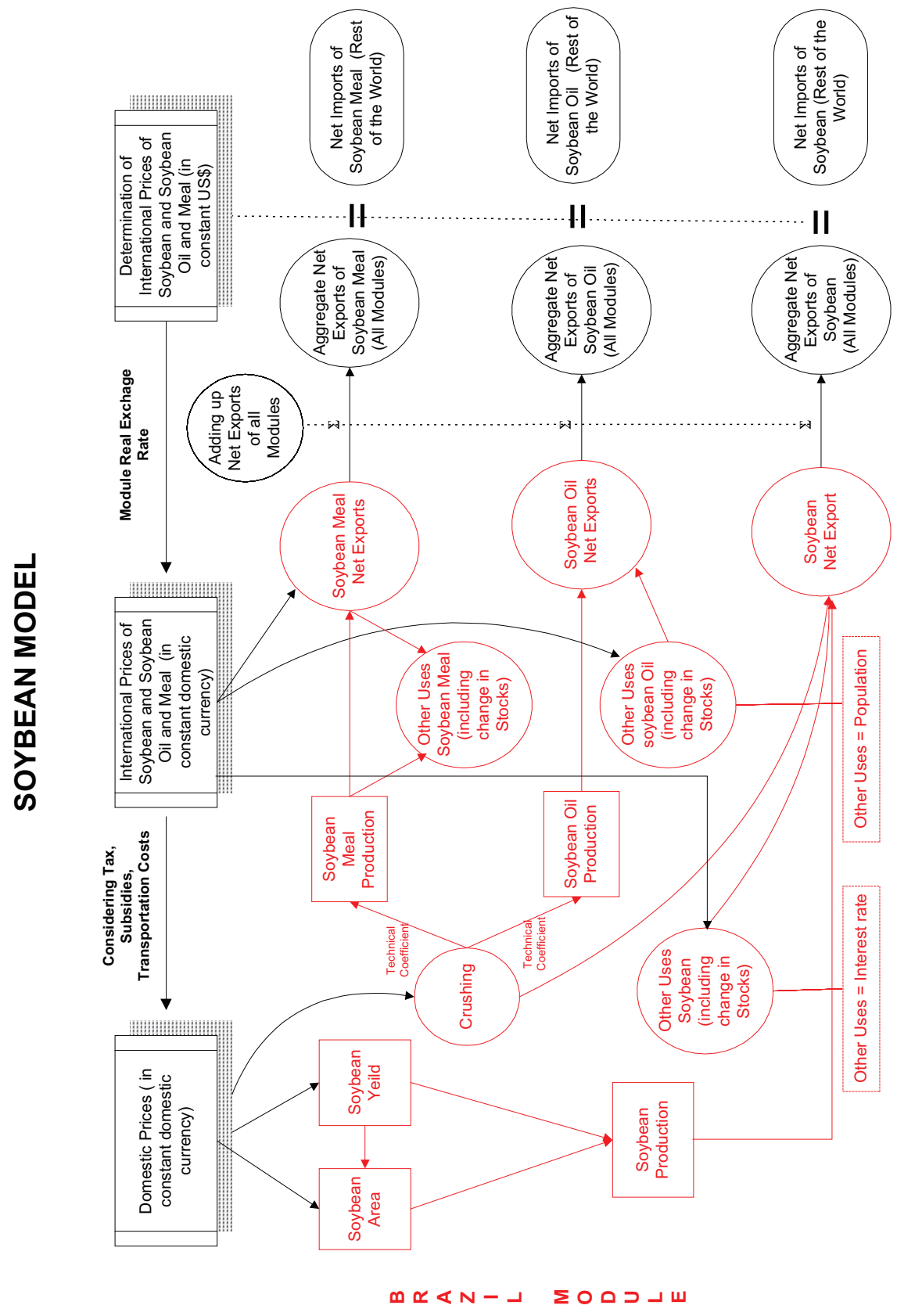

RER, Rio de Janeiro, vol. 44, no 04, p. 631-676, out/dez 2006 - Impressa em dezembro 2006 


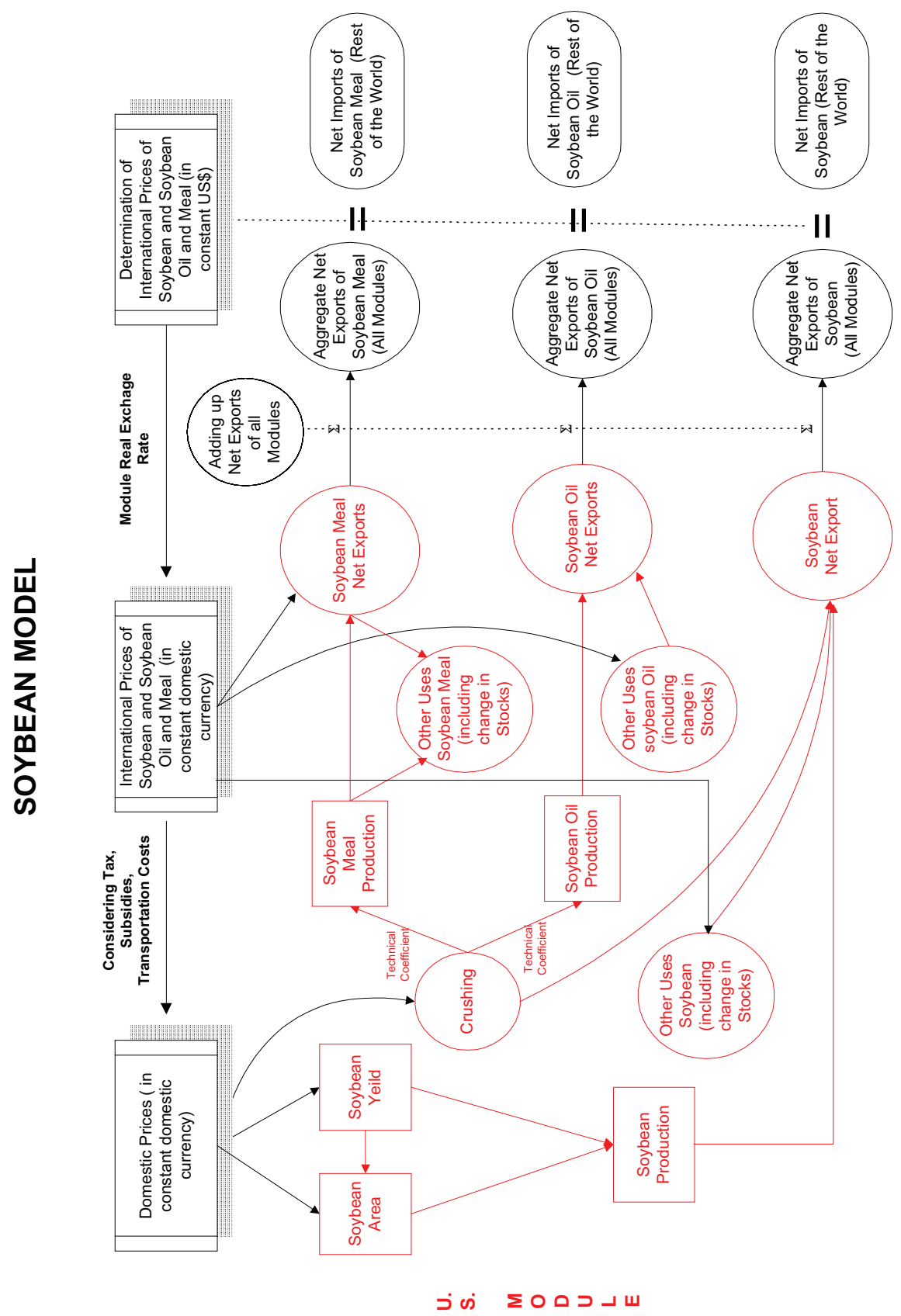

RER, Rio de Janeiro, vol. 44, no 04, p. 631-676, out/dez 2006 - Impressa em dezembro 2006 


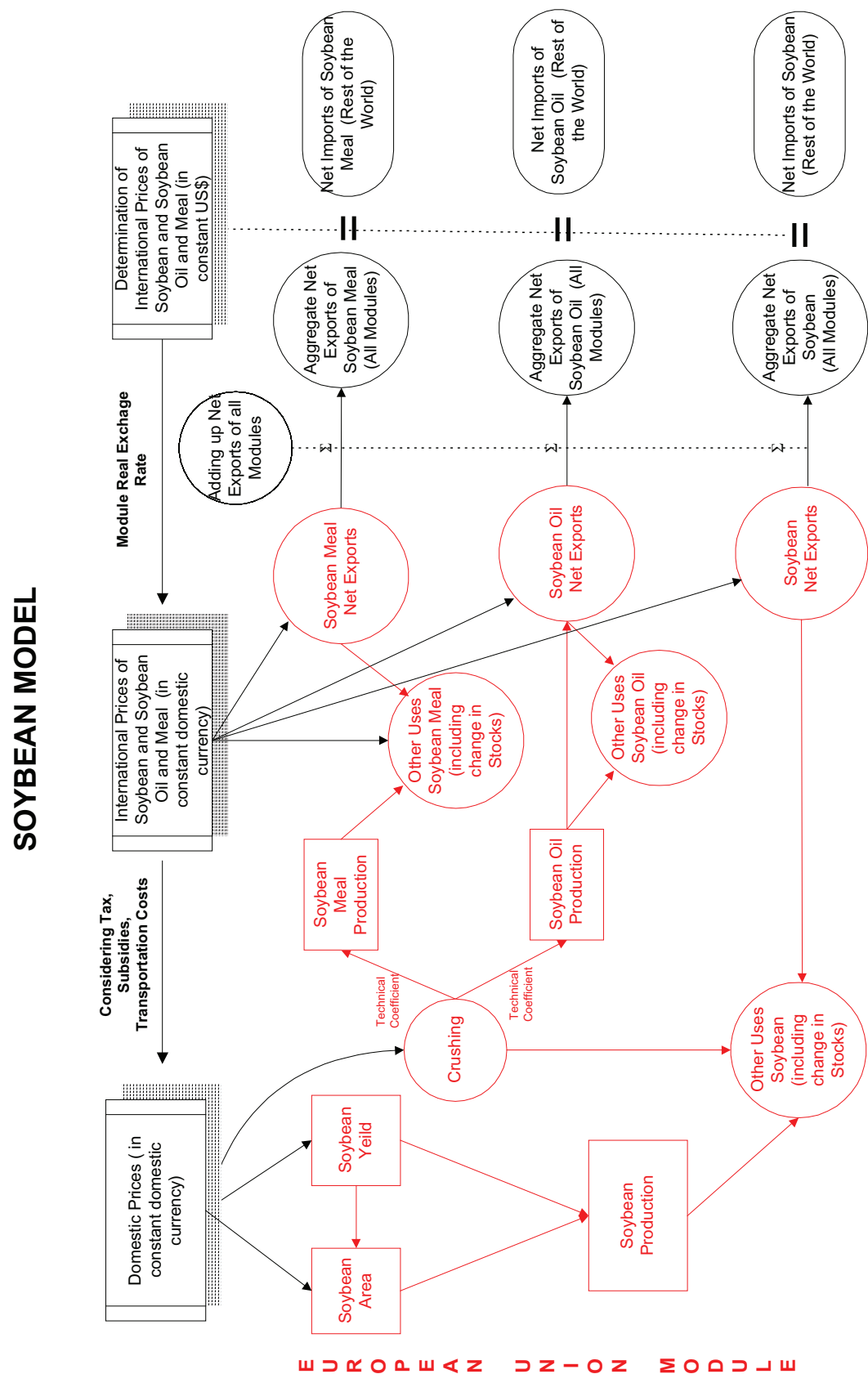

Recebido em junho de 2006 e revisto em outubro de 2006. 